\title{
TEST CESTY: NORMATIVNÍ ČESKÁ DATA PRO ŽÁKY 9. TŘíD ZŠ AŽ 4. ROČNÍKŮ SS̆
}

\author{
HANA SOKOLOVÁ ${ }^{1}$, HYNEK CÍGLER ${ }^{2}$ \\ ${ }^{1}$ Pedagogicko psychologická poradna Nový Jičín \\ ${ }^{2}$ Katedra psychologie, Fakulta sociálních studií Masarykovy univerzity
}

\begin{abstract}
Abstrakt: Vpředkládané studii jsou uvedena normativní česká data pro neuropsychologickou zkoušku Test cesty pro žáky 9. tříd základních škol až 4. ročníkü středních škol. Potvrdilo se, že není možné přejímat výsledky Testu cesty z jiného kulturního kontextu. Čeští studenti podali statisticky významně horší výkony ve srovnání $s$ českým manuálem $k$ metodě uváděnými normami ze zahraničí $i$ ve srovnání s daty jiných zahraničních studií. Dále byly identifikovány faktory, které významně souvisí s výsledem $v$ Testu cesty u skupiny českých adolescentů - typ navštěvované střední školy a ročník studia, vprotikladu svýsledky jiných výzkumů se neprokázala souvislost výkonu $s$ věkem. Ověrovány byly také psychometrické charakteristiky metody. Pro praktické využití odbornými pracovníky je uveden metodický list pro práci s normami. Získaná data pomohou klinickým psychologům při hodnocení neurologického oslabení dospívajících, mohou být užitečná také pro pracovníky pedagogicko-psychologických poraden lépe identifikovat žáky s možnou potřebou podpůrných opatření ve vzdělávání.
\end{abstract}

Klíčová slova: Test cesty, dospívající, normy pro českou populaci

\section{Úvod}

Test cesty (anglicky Trail Making Test) byl vytvořen již v roce 1938 Partingtonem pod názvem „Zkouška distribuované pozornosti“ s cílem měřit psychomotorické tempo, schopnost integrovat více jednoduchých naučených podnětů a přepínat mezi nimi. Později Partington s Leiterem objevili souvislost výkonu v testu s inteligencí a test přejmenovali na „Partingtonův test cesty“ (Partington \& Leiter, 1949). Ve studii z roku 1945 byla potvrzena souvislost výsledku v testu s inteligencí, test byl přejmenován na „Test cesty“ a zařazen do baterie sloužící k diagnostice schopností vojáků (Brown, Casey, Fisch, \& Neuringer, 1958). Od té doby byl test používán zejména v armádě, než byl

\footnotetext{
1 Pedagogicko psychologická poradna Nový Jičín, Žižkova 3, 74101 Nový Jičín

2 Katedra psychologie, Fakulta sociálních studií MU, Joštova 10, 602 00, Brno

Doručeno do redakce: 15. 5. 2018

Příprava publikace byla podpořena grantem GAČR GA17-09797S.
} 
následně zařazen jako jedna ze zkoušek do Halstead-Reitanovy neuropsychologické baterie (Mitrushina, Boone, Razani, \& D’Elia, 2005; Preiss \& Preiss, 2006).

Dnes patří Test cesty ve světě mezi nejpoužívanější neuropsychologické zkoušky zejména pro diagnostiku pozornosti a deficitů exekutivních funkcí (Rabin, Barr, \& Burton, 2005; Willcutt, Doyle, Nigg, Faraone, \& Pennington, 2005), dále také pro odhalení kognitivních deficitů napr. u Alzheimerovy nebo Parkinsonovy choroby, při poranění mozku (Armstrong, Allen, Donohue, \& Mayfield, 2008; Bezdicek et al., 2012; Soukup, Ingram, Grady, \& Schiess, 1998), apod. V České republice není dle dostupných informací zatím používání tohoto nástroje tak rozšiřrené jako v zahraničí. Ve studii zabývající se mapováním nejpoužívanějších psychodiagnostických metod v ČR Test cesty neuvedl žádný z oslovených respondentů $(\mathrm{N}=241)$, včetně respondentů pracujících v oblasti klinické psychologie (N=78) mezi své tři nejpoužívanější zkoušky (Urbánek, 2010). Ze starších dat Svobody et al. (2004, cit. dle Urbánek, 2010) je patrné, že Test cesty ve své praxi používalo právě 11 \% oslovených českých klinických psychologů, kolegové z jiných oblastí psychologie jeho užívání neuvedli.

Test je kromě klinické psychologie možné využít také např. psychology v pedagogickopsychologických poradnách při hodnocení deficitů regulace aktivity a pozornosti (ADHD, v poradenském kontextu vývojové poruchy chování - dále VPCH) a rychlosti dítěte ve vztahu ke školním výkonům (Preiss \& Preiss, 2006).

Verze Testu cesty pro dospělé (od 15 let) v části A obsahuje 25 čísel, v části B 13 čísel a 12 písmen $(\mathrm{A}-\mathrm{K})$, které má proband co nejrychleji a ve správném pořadí spojit. Měří se výsledný čas a zaznamenává se počet chyb. Česká verze testu je přejata z anglického originálu a upravena pro české prostředí - do verze B je oproti originálu navíc zařazeno písmeno „CH“ (Preiss \& Preiss, 2006).

Na výsledku jedince v testu se podílí jeho psychomotorické tempo. Část A je ovlivněna schopností vizuálního vyhledávání a mentálního mapování, část B je navíc považována za ukazatele kognitivních schopností, jako např. flexibility myšlení, schopnosti rozdělit pozornost k více podnětům najednou a přepínat mezi nimi (Chaytor, SchmitterEdgecombe, \& Burr, 2006; Sánchez-Cubillo et al., 2009). V rámci interpretace výsledků se pracuje také s odvozenými skóry: rozdílem TMTB-A, případně poměrem TMTB/A. Ty jsou dle řady autorů nejlepším indikátorem schopnosti exekutivní kontroly při minimalizaci vlivu psychomotorického tempa a vizuální percepce, a tedy nejlepším ukazatelem neurologického oslabení (Hester, Kinsella, Ong, \& McGregor, 2005; Sánchez-Cubillo et al., 2009). Kromě hodnoty těchto odvozených skórů svědčí pro podezření na ADHD zejména vyšší čas v části B a zvýšený počet chyb v testu (Barkley, Grodzinsky, \& DuPaul, 1992).

V českém prostředí je k dispozici 2. vydání Testu cesty z roku 2006, které vydalo nakladatelství Psychodiagnostika (Preiss \& Preiss, 2006). Toto vydání obsahuje nové normy z tzv. Pražských studií pro děti ve věku 9-14 let, pro dospívající a dospělou populaci doporučují autoři používat normy plynoucí z metaanalýzy výsledků 47 studií používajících Test cesty z let 1980-2004 s celkem 6317 účastníky, provedenou v r. 2005 
Mitrushinou a kolegy. Tyto normy jsou uvedeny pro jednotlivé věkové skupiny od 16 do 89 let a autoři zde nabízí také korekční tabulku dle let vzdělání. Právě věk a vzdělání se ukazují jako faktory významně související s výsledkem v Testu cesty (Mitrushina et al., 2005; Tombaugh, 2004). Někdy bývá uváděn také vliv pohlaví a inteligence, ale ani jeden z těchto faktorů se v uváděné metaanalýze neukázal jako významný (Mitrushina et al., 2005). Přes veškeré př́nosy zmiňované studie je nutné zmínit, že převážná většina reflektovaných výzkumů byla prováděna na dospělé populaci (pouze 4 studie zahrnují dospívající již od 15 let), proto uváděné hodnoty pro dospívající je nutné brát s rezervou. Navíc byly zjištěny rozdíly ve výsledcích $\mathrm{v}$ Testu cesty $\mathrm{v}$ jednotlivých státech, není tedy možné přejímat normy vytvořené v jiném kulturním kontextu (Fernández \& Marcopulos, 2008). To potvrzuje na svých datech také Bezdíček s kolegy (2012), kteří zaznamenali signifikantní rozdíly ve srovnání výsledků české dospělé populace (20-84 let) s nejkomplexnějšími soudobými normami pro dospělé Tombaugha (2004) i následným srovnáním výkonů zdravých českých dospělých s výsledky španělských a amerických respondentů (Bezdicek et al., 2016). V nejnovější studii Bezdíčka a kolegů (2017) pak byl i v českém prostředí pozorován výše zmíněný vliv věku a vzdělání na výsledky v Testu cesty u zdravé populace starších dospělých (60-96 let) - naopak vliv pohlaví pozorován nebyl, stejně jako v metaanalýze Mitrushiny a kolegů (2005).

Hlavním cílem této studie bylo získat normativní data pro věkovou skupinu 15-19 let pro Test cesty, která zatím v českém prostředí chybí. Studie byla součástí projektu, zaměřeném také na mapování čtenářských dovedností žáků 9. tříd základních škol (dále ZŠ) a 1. ročníků středních škol (dále SŠ). Dílčím cílem bylo na získaných datech ověřit psychometrické charakteristiky použitých metod. Touto prací bychom rádi také upozornili na uvedený diagnostický nástroj a přispěli k jeho častějšímu využití v České republice.

\section{Metoda}

\section{Výzkumný vzorek}

Byl použit záměrný, kvótní výběr, kdy kritériem pro rozřazení výzkumného vzorku byl stanoven typ školy, kterou žák navštěvuje. U žáků 1. až 4. ročníků SŠ jsme z jednotlivých výročních zpráv všech středních škol, gymnázií a odborných učilišt' regionu Novojičínsko, ve kterém probíhal sběr dat, zjistili celkové poměrové zastoupení žáků na jednotlivých typech škol ve školním roce předcházejícím sběru dat (2015/2016). Dozvěděli jsme se, že 48,5 \% žákủ studovalo na střední škole s maturitou, 25,9 \% žákủ na gymnáziích a 25,6 \% žáků si vybralo učební obor. U žáků 9. tříd ZŠ a odpovídajícího ročníku osmiletého gymnázia jsme vycházeli z výroční zprávy Moravskoslezského kraje o stavu a rozvoji vzdělávací soustavy v MS kraji za školní rok 2015/2016 (2017), který udává, že v našem kraji odchází 7,3 \% žáků 5. tř́d na osmileté gymnázium. Konkrétní údaje pro region Novojičínsko se nám pro tuto věkovou skupinu nepodařilo dohledat.

Následně jsme oslovili ředitele vybraných škol s žádostí o spolupráci tak, abychom co nejlépe zachovali výše zmíněné zastoupení žáků na jednotlivých školách také v našem 
výzkumném souboru. Výběr konkrétních škol pak probíhal přiležitostným výběrem. Všichni ředitelé nám vyšli vstř̌́c a umožnili nám realizaci výzkumu v některých tř́dách svých škol.

Výhodou zvoleného postupu výběru vzorku je dostupnost respondentů a možnost zajistit co nejreprezentativnější vzorek z hlediska charakteristik, které se ve vztahu k výsledkům TMT ukázaly v dřívějších výzkumech jako významné (tj. z hlediska vzdělání, věku, s určitou mírou pravděpodobnosti také inteligence jako faktorem do určité míry souvisejícím se vzděláním). To se nám však podařilo pouze částečně, nebot' skutečné zastoupení žáků z jednotlivých typů škol bylo v našem výzkumném souboru následující: 1.-4. ročníky SŠ: gymnázia $32,5 \%$, střední školy s maturitou $50,5 \%$, střední odborné učiliště 17,0 \%; 9. tř́da ZŠ: základní škola 71,6 \%, gymnázium 28,4 \%. Nevýhodou tohoto výběru vzorku je absence záruk reprezentativnosti souboru z jiných hledisek a místní charakter norem. Důsledky podrobně zvažujeme v diskuzi.

\section{Použité metody}

Test cesty (ang. TrailMaking Test) se skládá ze dvou částí - A a B, které jsme administrovali ve formě tužka - papír.

\section{Výzkumný design}

Sběr dat probíhal přímo ve školách. Studenti byli nejdříve skupinově poučeni o průběhu a cílech výzkumu, byli informováni o dobrovolnosti a anonymitě šetření. Následně byli žáci, jejichž rodiče souhlasili s účastí svých dětí ve výzkumu, po jednom bráni do vyhrazené místnosti. Nejdříve dostali prostor k doplňujícím otázkám, poté s nimi byl proveden anamnestický rozhovor, $v$ rámci kterého byli zároveň respondenti požádání o subjektivní hodnocení své pozornosti a svého pracovního tempa (na škále 1-5 jako ve škole, tj. 1 je nejlepší). Následně jim byl administrován TMT část A a část B (dle pokynů v manuálu) a poté byli respondenti opět požádání o subjektivní hodnocení své pozornosti (studenti věděli, že právě vyplnili test, který se mj. používá k hodnocení pozornosti). Žákům 9. tříd ZŠ a 1. ročníků SŠ byla následně zadána ještě zkouška čtení - tato data jsme využili pro další normalizační a samostatně publikovanou studii (v tomto čísle, s. 21-36).

\section{Popisné charakteristiky}

Celkově se projektu zúčastnilo 584 žáků a studentů z okresu Nový Jičín (z celkového počtu 740 oslovených žáků - tj. účast 78,9 \%) z celkem 8 škol - 3 základních škol, 1 gymnázia, 2 odborných učilišt' a 2 středních škol. Jednalo se o 388 dívek a 196 chlapců 9. ročníků ZŠ až 4. ročníků SŠ ve věku 15 - 24 let (ve vzorku bylo několik studentů, kteří z různých důvodů studovali SŠ později nebo déle; po pečlivé úvaze a vzhledem ke slabým korelacím testových výsledků s věkem jsme je ve vzorku nakonec ponechali). Chlapci a dívky se nelišili z hlediska věku v celých letech, Fisherův exaktní test (Monte Carlo simulace) $p(584)=0,098$. V tabulce 1 je uvedeno rozložení výzkumného vzorku z hlediska ročníku, pohlaví a typu navštěvované školy.

Tabulka 1 Popis výzkumného vzorku 


\begin{tabular}{|l|c|c|c|c|c|c|c|c|c|}
\hline & \multicolumn{3}{|c|}{ ZŠ } & \multicolumn{2}{c|}{ Gymnázium } & \multicolumn{3}{c|}{ SŠ } & \multicolumn{2}{c|}{ SOU } & $\begin{array}{c}\text { Celke } \\
\text { m }\end{array}$ \\
\hline & Dívky & Chlapci & Dívky & Chlapci & Dívky & Chlapci & Dívky & Chlapci & \\
\hline 9. třída & 33 & 15 & 13 & 6 & - & & - & & 67 \\
\hline $\begin{array}{l}1 . \\
\text { ročník }\end{array}$ & - & - & 21 & 19 & 56 & 12 & 12 & 17 & 137 \\
\hline $\begin{array}{l}2 . \\
\text { ročník }\end{array}$ & - & - & 24 & 16 & 46 & 19 & 13 & 12 & 130 \\
\hline $\begin{array}{l}3 . \\
\text { ročník }\end{array}$ & - & - & 26 & 12 & 57 & 8 & 11 & 23 & 137 \\
\hline $\begin{array}{l}4 . \\
\text { ročník }\end{array}$ & - & - & 26 & 24 & 50 & 13 & - & - & 113 \\
\hline & 33 & 15 & 110 & 77 & 209 & 52 & 36 & 52 & \\
\hline Celkem & \multicolumn{2}{|c|}{48} & \multicolumn{2}{|c|}{187} & \multicolumn{2}{c|}{261} & & & \\
\hline
\end{tabular}

$\mathrm{Z}$ celkového počtu probandů nikdy nebylo $\mathrm{v}$ péči PPP 446 dětí, 73 dětí ano - at' už v současnosti, nebo v minulosti. Aktuálně dochází do PPP 47 dětí a studentů - 36 pro VPU, 2 pro VPCH a 9 pro VPU i VPCH zároveň.

U odborného lékaře - neurologa - je nyní vedeno 37 dětí, nejčastěji pro migrény a bolesti hlavy, bolesti zad a krční páteře, poruchy pozornosti, epilepsii, př́padně po úrazech hlavy. U psychiatra je v současnosti vedeno 14 dětí - pro poruchy pozornosti, úzkostné poruchy, depresi a další onemocnění (např. anorexie, Aspergerův syndrom, specifické fobie). Jedno dítě je vedeno u obou odborníků. Léky na depresi, pozornost nebo úzkost nyní užívá 9 žáků - bohužel bližší informace o tom, jaký typ léků respondenti užívají, se nám nepodařilo získat.

Všichni tito respondenti byli ponecháni ve vzorku i za účelem konstrukce norem.

\section{Postup zpracování dat}

Všechna dostupná data byla členy projektového týmu přepisována do programu MS Excel, následně byla převedena do programu IBM SPSS 20.0, ve kterém probíhala statistická analýza dat. Velikost efektu (Cohenovo d) byla počítána za využití kalkulačky dr. Beckera ${ }^{3}$, pro výpočet t-testu při srovnání našich výsledků s výsledky dřive provedených studií pak jiná online kalkulačka4 ${ }^{4}$.

\section{Výsledky}

\section{Faktory související s výkonem žáků}

Nejdříve jsme se zajímali o to, které faktory souvisí s výsledkem probandů v TMT.

\section{Typ navštěvované školy}

Potvrdil se efekt typu navštěvované střední školy na výsledný čas pro základní i odvozené skóry: část $A: F(2 ; 530)=15,52, p<0,001, \mu=0,23$, část $B$ - Welchův test $F(2 ; 210,4)=19,91$, $\mathrm{p}<0,001$, rozdíl TMTB-A: Welchův test $\mathrm{F}(2 ; 215,7)=14,67, \mathrm{p}<0,001$ i podíl TMTB/A:

\footnotetext{
${ }^{3}$ https://www.uccs.edu/ lbecker/

${ }^{4}$ https://www.graphpad.com/quickcalcs/ttest1/?Format=SD
} 
$\mathrm{F}(2 ; 527)=3,20, \mathrm{p}=0,041$. Dle předpokladů zkoušku nejlépe zvládli studenti gymnázia, naopak nejhůře se vedlo studentům odborných učilišt' (viz Tabulka 2).

Tabulka 2 Deskriptivní ukazatele výsledků TMT části A a B dle typu navštěvované SŠ

\begin{tabular}{|l|c|c|c|c|c|c|c|c|c|}
\hline & N & \multicolumn{2}{|c|}{ TMT A } & \multicolumn{2}{c|}{ TMT B } & \multicolumn{2}{c|}{ TMT B-A } & \multicolumn{2}{c|}{ TMT B/A } \\
\hline & & $\mathrm{M}$ & SD & M & SD & M & SD & M & SD \\
\hline SOU & 87 & 33,74 & 12,51 & 81,79 & 30,18 & 48,89 & 26,94 & 2,58 & 1,05 \\
\hline SŠ & 261 & 27,25 & 9,41 & 63,28 & 21,25 & 37,25 & 19,87 & 2,46 & 0,96 \\
\hline Gymnázium & 166 & 26,88 & 9,36 & 58,43 & 21,86 & 34,28 & 20,54 & 2,34 & 0,91 \\
\hline Celkem & 514 & 28,24 & 10,28 & 64,84 & 24,47 & 38,81 & 22,18 & 2,45 & 0,96 \\
\hline
\end{tabular}

Při srovnání výsledků žáků 9. ročníků navštěvujících základní školu nebo osmileté gymnázium mezi žáky nebyly nalezeny rozdíly: TMT A: $t(49)=0,35, p=0,726$; TMT $B$ : $\mathrm{t}(48)=0,81, \mathrm{p}=0,423$, TMTB-A: $\mathrm{t}(48)=0,72, \mathrm{p}=0,475$, TMTB/A: $\mathrm{t}(48)=0,57, \mathrm{p}=0,571$.

\section{Věk}

Očekávali jsme také vývoj výsledku v testu s věkem - ten se na našich datech nepotvrdil, TMTA: Kendalovo ${ }^{5} \tau=-0,04, p=0,208$; TMT části $B: \tau=-0,06, p=0,057$; TMTB-A, $\tau=-0,04$, $\mathrm{p}=0,208 ; \mathrm{TMTB} / \mathrm{A}, \tau=-0,01, \mathrm{p}=0,691^{6}$.

\section{Ročník}

Předpokládali jsme, že s postupem žáků do vyššího ročníku bude docházet ke zlepšování výkonu v TMT. Existuje statisticky významná souvislost mezi navštěvovaným ročníkem a výsledkem $\mathrm{v}$ TMT $\mathrm{v}$ části $\mathrm{A}$ - Kendalovo $\tau=-0,08, \mathrm{p}=0,017$, stejně jako $\mathrm{v}$ TMT části $\mathrm{B}$ Kendalovo $\tau=-0,09, p=0,006$, TMTB-A: $\tau=-0,06, p=0,045$. Efekt se neprojevil $u$ poměrového skóru TMTB/A, $\tau=-0,02, p=0,637$ a celkově byly efekty velmi slabé.

Tabulka 3 Deskriptivní ukazatele výsledků TMT dle ročníku

\begin{tabular}{|l|c|c|c|c|c|c|c|c|c|}
\hline & & \multicolumn{2}{|c|}{ TMT A } & \multicolumn{2}{c|}{ TMT B } & \multicolumn{2}{c|}{ TMT B-A } & \multicolumn{2}{c|}{ TMT B/A } \\
\hline & $\mathrm{N}$ & $\mathrm{M}$ & $\mathrm{SD}$ & $\mathrm{M}$ & $\mathrm{SD}$ & $\mathrm{M}$ & $\mathrm{SD}$ & $\mathrm{M}$ & SD \\
\hline 9. tř́́da & 50 & 31,43 & 10,76 & 68,62 & 26,74 & 37,20 & 24,76 & 2,31 & 0,94 \\
\hline 1. ročník & 136 & 30,31 & 12,17 & 68,61 & 25,83 & 38,81 & 22,18 & 2,45 & 0,96 \\
\hline 2. ročník & 130 & 27,01 & 9,21 & 63,80 & 25,40 & 36,79 & 22,60 & 2,47 & 0,87 \\
\hline 3. ročník & 135 & 27,80 & 9,43 & 68,10 & 24,48 & 40,19 & 21,65 & 2,58 & 1,02 \\
\hline 4. ročník & 113 & 27,70 & 9,79 & 57,63 & 19,86 & 29,93 & 18,46 & 2,23 & 0,88 \\
\hline
\end{tabular}

\section{Pohlaví}

Při srovnání výsledků žáků chlapců a dívek nebyly nalezeny rozdíly v TMT A: t(565)=1,12, $\mathrm{p}=0,263$; TMTB/A: $\mathrm{t}(561)=1,42, \mathrm{p}=0,156$. Naopak rozdíly mezi výkony chlapců a dívek

\footnotetext{
${ }^{5}$ Na tomto místě jsme zvolili Kendallův koeficient pořadové korelace, nebot’ jsme nepředpokládali lineární vztah věku a výkonu vzhledem k použité věkové skupině adolescentů. Protože porušení těchto předpokladů by mohlo zkreslit velikost síly efektu a jeho statistickou významnost při odhadu pomocí Pearsonovy korelace, rozhodli jsme se pro použití neparametrických metod. Vzhledem k menšímu počtu kategorií a těžším koncům rozložení jsme zvolili Kendallův korelační koeficient, nikoliv Spearmanův. Ten nicméně poskytuje velmi podobné výsledky: v případě věku $\rho_{A}=-0,05, \rho_{B}=-0,08, \rho_{B}-A=0,05, \rho_{B} / A=-0,02 ;$ v př́padě ročníku $\rho_{A}=-0,10^{*}, \rho_{B}=-0,12^{* *}, \rho_{B-A}=-0,08^{*}, \rho_{B} / A=-0,02$.
} 
byly nalezeny $\mathrm{v}$ TMT $\mathrm{B}$ : $\mathrm{t}(308,86)=2,68, \mathrm{p}=0,08$, a rozdílovém skóru TMTB-A: $\mathrm{t}(319,04)=2,46, \mathrm{p}=0,014$.

Tabulka 4 Deskriptivní ukazatele výsledků TMT dle pohlaví

\begin{tabular}{|l|c|c|c|c|c|c|c|c|c|}
\hline & N & \multicolumn{2}{|c|}{ TMT A } & \multicolumn{2}{c|}{ TMT B } & \multicolumn{2}{c|}{ TMT B-A } & \multicolumn{2}{c|}{ TMT B/A } \\
\hline & & M & SD & M & SD & M & SD & M & SD \\
\hline Chlapci & 190 & 29,21 & 11,12 & 69,39 & 28,50 & 40,14 & 24,79 & 2,51 & 0,97 \\
\hline Dívky & 373 & 28,18 & 9,94 & 63,04 & 22,22 & 35,02 & 20,13 & 2,39 & 0,93 \\
\hline
\end{tabular}

\section{Chybovost v testu}

Autoři české verze testu v př́ručce uvádí, že více než jedna chyba v části B je některými autory považována za závažnou. Chyby jsou přičítány zejména poškození mozku vlivem impulzivity nebo tendenci perseverovat. Dále však uvádí, že i zdraví lidé dělají poměrně dost chyb - 12 \% v části A, 35 \% v části B (Lezaková et al., cit. dle Preiss \& Preiss, 2006).

V tabulce 5 je uveden přehled počtu chyb respondentů v námi provedeném výzkumu pro část A i B.

V části B bylo maximem 7 chyb, které zaznamenal 1 student. Zajímavé je také srovnání úseku testu, ve kterém se jedinci chyby dopustili - významně více studentů udělalo chybu ve 2 . části TMTB, t(564)=-10,26, p $<0,001$, velikost efektu je střední, Cohenovo $d=0,6$.

Tabulka 5 Počet chyb v jednotlivých částech testu

\begin{tabular}{|l|c|c|c|c|}
\hline & \multicolumn{2}{|c|}{ část A } & \multicolumn{2}{c|}{ část B } \\
\hline počet chyb & rel. Frekvence & (kumulativní) & rel. frekvence & (kumulativní) \\
\hline 0 & $85,8 \%$ & $(100 \%)$ & $57,1 \%$ & $(100 \%)$ \\
\hline 1 & $12,3 \%$ & $(14,2 \%)$ & $29,2 \%$ & $(42,9 \%)$ \\
\hline 2 & $1,9 \%$ & $(1,9 \%)$ & $9,9 \%$ & $(13,7 \%)$ \\
\hline 3 & $0 \%$ & $(0 \%)$ & $3,2 \%$ & $(3,8 \%)$ \\
\hline 4 více & $0 \%$ & $(0 \%)$ & $0,6 \%$ & $(0,6 \%)$ \\
\hline
\end{tabular}

Chybovost a délka zpracování testu spolu v části A nesouvisí: $\tau=0,01, p=0,77$, naopak $\mathrm{v}$ části $\mathrm{B}$ je souvislost chybovosti a rychlosti zpracování statisticky významná: $\tau=0,40$, $\mathrm{p}<0,001$.

\section{Odvozené skóry}

\section{Poměr B/A}

Dle Mitrushiny a kolegů (2005) je možné interpretovat také poměr výsledků v TMT v části $\mathrm{B}$ a části $\mathrm{A}$. Dle informací v českém manuálu k metodě poměr nižší než 2 ukazuje na oslabení výkonu v části A, poměr vyšší než 3 ukazuje na oslabení výkonu v části B. Poměr v rozmezí 2-2,5 je možné brát jako normu, 3 jako kritický skór pro neurologické oslabení.

Na našich datech byl průměrný podíl TMTB/A $M=2,45$ při relativně vysoké $S D=0,96$. Horší výkon než je doporučovaný kritický skór 3 v našem výzkumu dosáhlo 20,96 \% žáků. Jak bylo zmíněno výše, typ navštěvované střední školy se ukázal jako faktor významně související s odvozeným skórem TMTB/A. Pokud se podíváme na kritický skór 3 pro 
jednotlivé školy, dosáhlo ho 27,6 \% studentů SOU, 19,5 \% studentů SŠ a 17,2 \% žáků gymnázia. Vzhledem knenormálnímu rozložení dat je však přesnější stanovovat poměrový kritický skór pro neurologické oslabení na našich datech přes percentilové hodnoty - ty jsou uvedeny v tabulce níže.

Tabulka 6 Kritické skóry pro neurologické oslabení

\begin{tabular}{|c|c|c|c|}
\hline \multicolumn{3}{|c|}{ TMTB/A } \\
\hline & SOU & Š̌ & Gymnázium \\
\hline 85. percentil & 3,54 & 3,32 & 3,08 \\
\hline 95. percentil & 4,39 & 4,66 & 4,17 \\
\hline
\end{tabular}

\section{Rozdíl B-A}

V interpretacích testu autoři různých studií často pracují také s rozdílem v TMTB-A. Na ten je výhodné se rovněž podívat, nebot' je dle některých autorů (např. Sanchéz- Cubillo et al, 2009) nejlepším ukazatelem schopnosti exekutivní kontroly při minimalizaci vlivu vizuální percepce a pracovní paměti.

Skór TMTB-A v námi provedeném šetření významně koreluje s prostým TMT B skórem $(\mathrm{r}=0,91, \mathrm{p}<0,001)$, rozdílový skór tedy na našich datech nepřináší oproti prostému TMTB skóru př́liš informací navíc.

\section{Normy}

Normy jsou stratifikované dle faktorů, které se ukázaly jako významně související s výkonem žákům v TMT (viz Př́loha 1) a prezentujeme je pomocí percentilů a vážených skórů odpovídajících jednotlivým hrubým skórům. Percentily byly zjištěny na základě rozložení dat a převedeny na vážené skóry na základě McCallovy plošné transformace. Protože používáme tzv. „norm-referenced“ interpretaci testových výsledků a protože hrubé skóry jsou arbitrární (a závislé na počtu podnětových bodů a designu testu), použití hrubých skórů je rovněž arbitrární. Interpretace s použitím hrubých skórů je tedy taktéž možná.

\section{Srovnání výkonů českých žáků $s$ dostupnými daty}

Srovnali jsme výkony našich respondentů s výkony uvedenými v manuálu k metodě (Preiss \& Preiss, 2006). Ve srovnání s daty Fromm-Aucha a Yeudalla (1983, cit. dle Preiss \& Preiss, 2006) je patrné, že v námi provedeném výzkumu podali čeští studenti ve věku 15-17 let horší výkony v TMTA: $\mathrm{t}(371)=2,78, \mathrm{p}=0,006$; velikost účinku je střední: Cohenovo $d=0,6$; i v TMTB: $\mathrm{t}(371)=4,21, \mathrm{p}=0,0001$, s velkou velikostí účinku Cohenovo $d=0,9$. Taktéž starší čeští respondenti ve věku $18-23$ let podali horší výkon než stejně staří kanadští studenti v TMTB: $\mathrm{t}(296)=3,96, \mathrm{p}=0,0001$; Cohenovo $d=0,6$; naopak v TMTA se jejich výkony neliší: t(296)=1,08, p=0,28; Cohenovo $d=0,1$.

Dále jsou v českém manuálu k metodě uvedena data z metaanalýzy Mitrushiny a kolegů (2005, cit. dle Preiss \& Preiss, 2006), která však byla získána interpolací např́íc věkovými skupinami a není tak k dispozici velikost vzorku pro naši kohortu. Velikost vzorku byla nicméně aproximována na základě reportovaného intervalu spolehlivosti a interpolované 
směrodatné odchylky a spočítána stejným způsobem jako v předchozích př́ípadech. Rozdíl byl i zde signifikantní a se střední velikostí účinku, a to jak v případě TMT A: $t(546)=3,54, p=0,0004$ s Cohenovým $d=0,5$, tak i v př́padě TMT B: $t(546)=3,65$, $p=0,0003$ s Cohenovým $d=0,5$.

Podařilo se nám dohledat také data Eliase et al. (1993, in Soukup, 1998), ze kterých částečně Mitrushina et al. vychází ve své metaanalýze (2005). Také ve srovnání s nimi je výkon současných českých adolescentů horší v obou částech zkoušky, s velkou velikostí účinku: TMTA: t(395)=3,92, p=0,0001; Cohenovo $d=1,05$; TMTB: t(395)=3,48, p=0,0006; Cohenovo $d=0,9$.

Deskriptivní statistiky všech studií jsou uvedeny v tabulce 6. Je evidentní, že český vzorek dosáhl výrazně horších výkonů oproti zahraničním vzorkům. Využívání dat z mezinárodních studií tak není př́liš vhodné.

Tabulka 7 Deskriptivní ukazatele srovnávaných studií

\begin{tabular}{|c|c|c|c|c|c|c|c|c|c|}
\hline \multirow[b]{2}{*}{ Zdroj } & \multirow[b]{2}{*}{ Autoři } & \multirow[b]{2}{*}{ Rok } & \multirow[b]{2}{*}{ Věk } & \multirow[b]{2}{*}{ Pohlaví } & \multirow[b]{2}{*}{$\mathrm{N}$} & \multicolumn{2}{|c|}{ TMT A } & \multicolumn{2}{|c|}{ TMT B } \\
\hline & & & & & & $M$ & SD & $\mathrm{M}$ & SD \\
\hline $\begin{array}{c}\text { Preiss \& } \\
\text { Preiss } \\
\text { (2006) }\end{array}$ & $\begin{array}{c}\text { Fromm- } \\
\text { Auch\&Yeudall }\end{array}$ & 1983 & $15-17$ & $\mathrm{M} / \mathrm{F}$ & 32 & 23,4 & 5,9 & 47,7 & 10,4 \\
\hline \multicolumn{2}{|c|}{ PPP NJ } & 2018 & $15-17$ & $\mathrm{M} / \mathrm{F}$ & 341 & 28,83 & 10,89 & 66,97 & 25,64 \\
\hline $\begin{array}{c}\text { Preiss \& } \\
\text { Preiss } \\
(2006)\end{array}$ & $\begin{array}{c}\text { Fromm- } \\
\text { Auch\&Yeudall }\end{array}$ & 1983 & $18-23$ & $\mathrm{M} / \mathrm{F}$ & 76 & 26,7 & 9,4 & 51,3 & 14,6 \\
\hline \multicolumn{2}{|c|}{ PPP NJ } & 2018 & $18-23$ & $\mathrm{M} / \mathrm{F}$ & 222 & 28,06 & 9,52 & 62,24 & 22,9 \\
\hline $\begin{array}{l}\text { Soukup } \\
\text { (1998) }\end{array}$ & Elias et al. & 1993 & $15-24$ & $\mathrm{M}$ & 37 & 21,46 & 7,6 & 57,7 & 27,98 \\
\hline \multicolumn{2}{|c|}{ PPP NJ } & 2018 & $15-24$ & $\mathrm{M}$ & 190 & 29,21 & 11,12 & 69,39 & 28,5 \\
\hline $\begin{array}{l}\text { Soukup } \\
\text { (1998) }\end{array}$ & Elias et al. & 1993 & $15-24$ & $\mathrm{~F}$ & 24 & 20,17 & 4,16 & 43 & 11,46 \\
\hline \multicolumn{2}{|c|}{ PPP NJ } & 2018 & $15-24$ & $\mathrm{~F}$ & 373 & 28,18 & 9,94 & 63,39 & 28,5 \\
\hline $\begin{array}{c}\text { Preiss \& } \\
\text { Preiss } \\
(2006)\end{array}$ & $\begin{array}{l}\text { Mitrushina et } \\
\text { al. }\end{array}$ & 2005 & $16-19$ & $\mathrm{M} / \mathrm{F}$ & $83,2^{\mathrm{a}}$ & 23,97 & 7,63 & 53,92 & 20,12 \\
\hline \multicolumn{2}{|c|}{ PPP NJ } & 2018 & 16-19 & $\mathrm{M} / \mathrm{F}$ & 465 & 28,19 & 10,38 & 64,17 & 24,14 \\
\hline
\end{tabular}

${ }^{a}$ Aproximace za pomoci reportovaného intervalu spolehlivosti, $C_{95 \%}=[22,33 ; 25,62]$, a deskriptiv.

\section{Reliabilita a validita}

\section{Split-half reliabilita}

Reliabilita byla odhadována metodou split-half. $\mathrm{V}$ průběhu vyplňování testu byl zaznamenán čas probanda v polovině TMT v části A i B. Následně jsme dopočítali hodnotu reliability pomocí korelace času v obou polovinách testu korigované prostřednictvím tzv. Spearman-Brownova prorockého vzorce. Protože je patrná významná souvislost výsledku s ročníkem studia, odhadli jsme reliabilitu zvlášt' pro jednotlivé ročníky. Tento postup má určité limity; v př́padě, že obě poloviny testu nejsou striktně paralelní, může 
být odhad mírně zkreslený (Lord \& Novick, 1968, s. 135). Dalším předpokladem je pak nezávislost chyb měření v obou polovinách testu, přičemž neexistuje žádný postup, jak tuto „lokální závislost“ detekovat (blíže viz Eisinga, te Grotenhuis, \& Pelzer, 2013). Odhady prezentované v tabulce 8 je tedy nutné brát s rezervou.

Tabulka 8 Odhad reliability pro jednotlivé ročníky

\begin{tabular}{|c|c|c|c|c|}
\hline & TMT A & TMTB & TMT B-A & TMTB $/ \mathbf{A}$ \\
\hline 9. tř́da & 0,83 & 0,59 & 0,51 & 0,40 \\
\hline 1. ročník & 0,85 & 0,56 & 0,43 & 0,44 \\
\hline 2. ročník & 0,67 & 0,65 & 0,48 & 0,31 \\
\hline 3. ročník & 0,76 & 0,47 & 0,24 & 0,36 \\
\hline 4. ročník & 0,66 & 0,55 & 0,24 & 0,25 \\
\hline Medián & $\mathbf{0 , 7 6}$ & $\mathbf{0 , 5 6}$ & $\mathbf{0 , 4 3}$ & $\mathbf{0 , 3 6}$ \\
\hline
\end{tabular}

\section{Obsahová validita}

Výsledky částí TMTA a TMTB spolu významně korelují $r=0,46, p<0,001$. Velmi zajímavá je významná negativní souvislost výsledku TMTA a poměrového skóru TMTB/A, což naznačuje, že čím respondenti pracovali pomaleji, tím lepší byla jejich exekutivní kontrola.

TMTB-A je dle Chaytora et al. (2006) více než TMTB/A závislý na výsledku TMTB, což se potvrdilo také na našich datech, $r=0,91, p<0,001$. Souvislost je vysoká do té míry, že rozdílový skór TMTB-A oproti prostému TMTB skóru nepřináší navíc téměř žádné informace, na našich datech se tedy tento odvozený skór jeví jako nadbytečný.

TMTB-A významně souvisí také s poměrovým skórem TMTB/A, i zde je však patrné, že TMTB/A přináší také nové informace, pravděpodobně je tedy ovlivněn také dalšími faktory.

Tabulka 9 Souvislost jednotlivých TMT skórů - Pearsonovy korelační koeficienty

\begin{tabular}{|c|c|c|c|c|}
\hline Kritérium & TMT A & TMT B & TMTB-A & TMT B/A \\
\hline TMT A & - & $0,46^{* * *}$ & 0,05 & $\mathbf{- 0 , 4 1}$ *** $^{* *}$ \\
\hline TMT B & & - & $\mathbf{0 , 9 1}^{* * *}$ & $0,56^{* * *}$ \\
\hline TMT B-A & & & - & $\mathbf{0 , 8 3}$ \\
\hline
\end{tabular}

$* * * \mathrm{p}<0,001$

\section{Kriteriální validita}

Hledali jsme také vztah výsledků v testu s dalšími kritérii - výsledky testu jsme tedy korelovali s dalšími informacemi zjištěnými od respondentů. Uvádíme je zejména proto, že jsme se ve shodě s Borsboomem, Mellenbergem a Heerdenem (2004) pokusili poskytnout co nejvíce dostupných informací o fungování testu, aby mohla být jeho validita posuzována v kontextu tzv. nomologické sítě.

Subjektivní hodnocení vlastního tempa statisticky významně koreluje s výsledkem v TMT A, vlastní hodnocení své pozornosti před testem s žádným ze základních skórů a vlastní hodnocení své pozornosti po testu pak s TMT B skórem, přičemž respondenti věděli, že administrovaný test je mj. testem pozornosti. Zejména zaznamenaná souvislost 
hodnocení svého pracovního tempa a výsledku v TMT A je oporou pro tvrzení zmiňované v teoretické části, tedy že výkon v TMT v části A je významně ovlivněn psychomotorickým tempem jedince. Celkově vzorec vztahů v tabulce 8 odpovídá teoretickým předpokladům.

Tabulka 10 Korelační koeficienty TMT skórů s vlastním hodnocením

\begin{tabular}{|l|c|c|c|c|}
\hline Kritérium & TMT A & TMT B & TMTB-A & TMT B/A \\
\hline $\begin{array}{l}\text { Vlastní hodnocení své } \\
\text { pozornosti před testem }\end{array}$ & 0,05 & $-0,02$ & $-0,05$ & $-0,08^{*}$ \\
\hline $\begin{array}{l}\text { Vlastní hodnocení své } \\
\text { pozornosti po testu }\end{array}$ & 0,04 & $\mathbf{0 , 1 6 * * *}$ & $0,18^{* * *}$ & $0,13^{* * *}$ \\
\hline $\begin{array}{l}\text { Vlastní hodnocení svého } \\
\text { tempa }\end{array}$ & $\mathbf{0 , 1 1}^{* *}$ & 0,02 & $-0,02$ & $-0,08^{*}$ \\
\hline
\end{tabular}

${ }^{* *} \mathrm{p}<0,01 ;{ }^{* * *} \mathrm{p}<0,001$

Dále nás zajímaly souvislosti výsledků v TMT se školními známkami, vzděláním rodičů a výsledkem ve čtenářských zkouškách - ty byly získány díky realizaci paralelní studie mapující zkoušky čtenářských dovedností a konkrétněji měřeny jako počet správně přečtených slov za 2 minuty (rychlost hlasitého čtení), čas potřebný k přečtení předem daného úseku textu (rychlost tichého čtení) a počet bodů získaných ve zkoušce porozumění (tiché čtení - porozumění) (blíže v tomto čísle, s. 21-36).

Tabulka 11 Přehled souvislosti TMT skórů s dalšími údaji (Kendallův korelační koeficient)

\begin{tabular}{|l|c|c|c|c|}
\hline Kritérium & TMT A & TMT B & TMTB-A & TMT B/A \\
\hline Známka z JČ & $0,11^{* *}$ & $0,17^{* * *}$ & $0,14^{* * *}$ & 0,05 \\
\hline Známka z M & $0,13^{* * *}$ & $0,23^{* * *}$ & $0,18^{* * *}$ & $0,08^{*}$ \\
\hline $\begin{array}{l}\text { Průměr všech známek na } \\
\text { poslední vysvědčení }\end{array}$ & $0,09^{* *}$ & $0,20^{* * *}$ & $0,16^{* * *}$ & 0,07 \\
\hline Vzdělání matky & $-0,03$ & $-0,12^{* * *}$ & $-0,12^{* * *}$ & $-0,08^{*}$ \\
\hline Vzdělání otce & $-0,06$ & $-0,11^{* *}$ & $-0,10^{* *}$ & $-0,05$ \\
\hline Hlasité čtení - rychlost & $-0,29^{* * *}$ & $-0,23^{* *}$ & $-0,13$ & 0,04 \\
\hline Tiché čtení - rychlost & $0,40^{* * *}$ & $0,29^{* * *}$ & 0,13 & $-0,05$ \\
\hline $\begin{array}{l}\text { Tiché čtení } \\
\text { porozumění }\end{array}$ & $-0,09$ & $-0,22^{* *}$ & $-0,22^{* *}$ & $-0,19^{*}$ \\
\hline
\end{tabular}

${ }^{*} \mathrm{p}<0,05{ }^{* *} \mathrm{p}<0,01 ;{ }^{* * *} \mathrm{p}<0,001$

Z tabulky 9 je možné vyčíst souvislost výsledku v TMT v obou částech se studijními výsledky žáků a jejich výkonem ve čtenářských zkouškách.

V případě části B je navíc patrný také vztah výsledků žáků se vzděláním jejich rodičů.

Je možné si povšimnout také výraznější souvislosti odvozeného skóru TMTB-A s uvedenými faktory (se stejnými jako prostý TMT B výsledek - viz patrná významná souvislost TMTB a TMTB-A, r=0,91). Poměrový skór TMTB/A s danými faktory nemá téměř žádnou souvislost. 


\section{Diskuze}

\section{Normativní česká data}

Na našich datech se ve shodě s Fernandezovou a Marcopulosovou (2008) potvrdilo, že není možné přejímat výsledky Testu cesty ze zahraničí. Čeští studenti podali horší výkony oproti výkonům kanadských a amerických adolescentů udávanými Soukupem (1998), stejně jako oproti normám uvedených $\mathrm{v}$ českém manuálu $\mathrm{k}$ metodě vycházejících $\mathrm{z}$ dat Fromm-Aucha a Yeudalla (1983, cit. dle Preiss \& Preiss, 2006). Hůře se jim vedlo také ve srovnání s manuálem uváděnou metaanalýzou Mitrushiny a kolegů (2005), kteří ke studiím Soukupa přidávají také další zdroje dat. Ve srovnání s těmito daty, doporučenými českými autory k používání, podali současní čeští studenti výrazně horší výkony v obou částech zkoušky. Zároveň byl do námi provedené studie zařazen výrazně vyšší počet respondentů. Na druhou stranu je nutné upozornit na to, že do našeho výzkumného souboru byli zařazeni pouze respondenti z jedné oblasti České republiky (okresu Nový Jičín), což díky rozdílným sociodemografickým charakteristikám jednotlivých regionů ČR mohlo výsledky ovlivnit. Vliv na výsledky může mít také způsob výběru vzorku - klastrový výběr, kdy jeho předností je snaha o co nejreprezentativnější vzorek $\mathrm{z}$ hlediska charakteristik, které se ve vztahu k výsledkům TMT ukázaly v dřivějších výzkumech jako významné (tj. vzdělání, věk). Tyto faktory - zejm. typ navštěvované školy (tj. vzdělání) a ročník studia (tj. faktor do určité míry související s věkem) se skutečně jako významné projevily i na našich datech. Je však třeba zmínit, že se v našem výzkumném vzorku nepodařilo zcela přesně zachovat požadované rozložení daných charakteristiky a nebyla tak přesně zachována reprezentativita těchto faktorů. Tento nedostatek by se mohl negativně projevit na souhrnných normativních výsledcích, proto je dle našeho názoru pro interpretaci výhodnější používat normy rozdělené dle typu navštěvované školy, které tento nedostatek překonávají. Obecnou nevýhodou našeho způsobu výběru vzorku je absence záruk reprezentativity z jiných hledisek (např. pohlaví, socioekonomický status, apod.). Přesto je možné předpokládat, že námi prezentované výsledky celkově lépe postihují výkony současných českých dospívajících a jsou tedy pro praktické využití vhodnější než normy přejaté ze zahraničí a doporučované v českém manuálu k metodě.

V dř́vějších studiích (např. Bezdicek et al., 2017; Mitrushina et al., 2005; Tombaugh, 2004) byla zjištěna souvislost výsledku v Testu cesty se vzděláním a inteligencí. Na našich datech se ukázalo, že typ navštěvované střední školy souvisí s výsledkem respondenta v Testu cesty. To lze chápat jako nepř́mou podporu vztahu inteligence a výsledkủ v Testu cesty, byt' souvislost inteligence a vzdělání není samozřejmě jednoznačná a př́má. Zároveň naše výsledky rozšiřují uvedené předchozí studie, protože na rozdíl od nich nepracují s dosaženým, ale právě probíhajícím vzděláním. V tomto ohledu bylo překvapivým zjištěním, že se neliší výkony žáků 9 . tříd základních škol a žáků osmiletého gymnázia. Jedním z možných vysvětlení tohoto překvapivého výsledku je fakt, že z žáků 9. tříd se projektu zúčastnilo nejméně ze všech oslovených žáků (39,7 \%), přičemž u žáků odpovídajícího ročníku gymnázia byla účast 82,8 \% ze všech oslovených. Výsledky žáků základních škol tak pravděpodobně méně reprezentují výsledky žáků 9 . tříd v dané místní 
populaci. Udávaná nižší účast žáků 9. tř́d v projektu je také jedním z limitů prezentované studie.

Dalším důležitým faktorem, ovlivňujícím výsledek v Testu cesty, je dle našich výsledků ročník studia. V protikladu s výsledky jiných výzkumů se neprokázala souvislost výkonu $\mathrm{s}$ věkem (Tombaugh, 2004). Domníváme se, že větší důležitost školního ročníku (tj. délky vzdělávání) vzhledem $\mathrm{k}$ výsledku v Testu cesty oproti věku studentů může souviset s tím, že míra a délka stimulace školních dovedností studentů je pro kvalitní zpracování tohoto typu úkolu důležitější než fyzický věk. Je možné, že se zvyšující se věkovou heterogenitou školních tř́d (odklady školní docházky, častější změny středních škol, aj.) může tento trend nabývat na významu.

Někteří autoři zmiňují také vliv pohlaví na výkony v Testu cesty, avšak dle metaanalýzy Mitrushiny a kolegů (2005) není pohlaví důležitým faktorem ovlivňující výkony zdravé dospělé populace. Taktéž na českých současných datech zdravé populace starších dospělých nebylo pohlaví potvrzeno jako významný faktor ovlivňující výkon v TMT (Bezdicek et al., 2017). Na našich datech se ukázalo, že pohlaví je faktorem hrajícím roli pouze $\mathrm{v}$ př́padě výsledku $\mathrm{v}$ Testu cesty části $\mathrm{B}$ (kde dívky podávaly nepatrně lepší výsledky), v části $\mathrm{A}$ byl výkon chlapců a dívek srovnatelný. Sekundárně pak tyto výsledky ovlivnily také odvozené skóry - poměrový skór B/A je u dívek a chlapců srovnatelný, což neplatí pro rozdílový skór TMTB-A. Je však důležité zmínit, že ve vzorku našich respondentů nebylo srovnatelné zastoupení dívek a chlapců, dívek se zúčastnilo výrazně více. Protože se výkony dívek a chlapců v Testu cesty v části B liší, může mít jejich nestejné zastoupení vliv na celkové souhrnné výsledky. Ten by však měl být minimální.

$\mathrm{V}$ př́loze č. $1 \mathrm{k}$ tomuto článku jsou uvedeny metodické listy pro používání vytvořených norem praktiky. Normy jsou stratifikované dle faktorů, které se v naši studii ukázaly jako významné - dle ročníku studia a následně dle ročníku studia pro jednotlivé typy škol, které respondenti navštěvují. Domníváme se, že toto členění by mohlo být pro praktiky výhodné $\mathrm{z}$ toho důvodu, že je možné srovnat výkony respondentů v rámci ročníkové normy, ale také v rámci prostředí, ve kterém student působí. Na základě toho pak mohou být př́padná doporučení pro práci se studenty nejen ve školním kontextu lépe cílená.

\section{Reliabilita a validita metody}

Reliabilita a validita původní metody (Comprehensive Trail-Making test) je v zahraničí považována za velmi dobře ověřenou (Thompson, 2003, cit. dle Motýl, 2015). Je proto škoda, že v českém manuálu k metodě nejsou údaje o reliabilitě původní metody explicitně uvedeny. Jako ukazatel reliability je možné brát uvedenou informaci o vysoké míre korelace $(0,73-0,90)$ mezi alternativními formami testu, vytvořenými prostou změnou postupu při zachování lokalizace koleček (Preiss \& Preiss, 2006). Odkazovaný výzkum však proběhl na datech získaných při použití původní (nikoliv české) verze metody. 
Na našich datech jsme reliabilitu Testu cesty odhadovali metodou split-half pomocí Spearmanova-Brownova vzorce. Při interpretaci našich výsledků je nicméně nutné mít na paměti limity v podobě předpokladu ekvivalence obou polovin testu a zejména jejich lokální nezávislosti, tedy nekorelovaných chyb měření (blíže viz Eisinga, te Grotenhuis a Pelzer, 2013). Samotné odhady vnitřní konzistence jsou rozdílné pro jednotlivé části testu. $\mathrm{V}$ části A je výsledek relativně dobrý a srovnatelný s uváděnými hodnotami $(\mathrm{r}=0,76), \mathrm{v}$ části $\mathrm{B}$ je výsledek méně uspokojivý $(\mathrm{r}=0,56)$, pro odvozené skóry pak ještě nižší (pro TMTB-A r=0,43, pro TMTB/A r=0,36). Možným vysvětlením snížené hodnoty reliability části $B$ může být úprava podnětového materiálu při přejímání testu ze zahraničí. Do české verze části B bylo přidáno písmeno „ $\mathrm{CH}^{4}$, které obsahuje česká abeceda. Při administraci metody významně více žáků chybovalo ve 2. části TMTB (tj. právě tam, kde se objevuje písmeno „CH“). Protože chybovost v testu a celkový čas v části B spolu významně souvisí, může snížená hodnota split-half reliability pro část B souviset právě s touto skutečností (a následně pak také ovlivnit reliabilitu odvozených skórů). Této domněnce odpovídají také zkušenosti výzkumníků z administrace metody, kdy pozorováním bylo zaznamenáno, že řada studentů spojovala H-9-I místo H-9-CH. Taktéž po ukončení testu někteří studenti tento fakt zmiňovali. Pravděpodobně vlivem věku respondentů a rozvojem používání nových technologií má řada studentů nyní lépe zautomatizovanou anglickou abecedu než tu českou. Zmiňované vlivy by pak mohly být vysvětlením, proč autoři české prríručky toto úskalí při vydání testu v r. 2006 nereflektovali. Snížená hodnota reliability části B může však být vysvětlena také např. tím, že druhá polovina části $B$ je pro respondenty obtížnější vzhledem k únavě nebo k menší automatizaci znalosti střední části abecedy.

Na validitu metody autoři českého manuálu usuzují dle schopnosti nástroje predikovat samostatnost v běžných životních aktivitách (Preiss \& Preiss, 2006). Údaje o reliabilitě a validitě metody uvedené v prŕručce ve shodě s Motýlem (2015) nepovažujeme za dostačující. Na našich datech jsme validitu nástroje dokazovali pomocí hledání vztahu výsledků v daném testu $\mathrm{s}$ dalšími kritérii, ověřování vztahů jednotlivých skórů testu (základních i odvozených) a pomocí hledání schopnosti testu diskriminovat mezi různými skupinami respondentů. Dále jsme se ve shodě s Borsboomem, Mellenbergem a Heerdenem (2004) pokusili poskytnout co nejvíce dostupných informací o fungování testu, aby mohla být jeho validita posuzována v kontextu tzv. nomologické sítě.

Ukázala se statisticky významná, ale nikterak velká (všechna $\mathrm{r}<0,23$ ), souvislosti výsledku v TMT se školními známkami na poslední vysvědčení ( $M$, JČ, celkový průměr). Tento údaj uvádí na svých datech také Preiss a Preiss (2006), uváděné korelace u mladší české populace (9-14 let) však na rozdíl od námi provedeného výzkumu nebyly statisticky významné. Zdá se, že s věkem se souvislost výsledku v Testu cesty se školními známkami zesiluje. Zajímavé je v dalším srovnání s daty Preisse a Preisse (2006) potvrzení souvislosti výkonu v Testu cesty se vzděláním rodičů - na našich datech i na datech prezentovaných $\mathrm{v}$ českém manuálu k metodě se projevila souvislost výkonu v Testu cesty v části B se vzděláním matky i otce, přičemž souvislost výkonu v Testu cesty v části A se vzděláním rodičů nebyla nalezena ani v jedné ze studií. Na našich datech jsme navíc měli 
možnost hledat souvislost výkonu v TMT A i v TMT B s rychlostí hlasitého i tichého čtení - ta byla u základních skórů prokázána. Domníváme se, že vysvětlením této souvislosti by mohlo být psychomotorické tempo, které ovlivňuje výkony v obou zkouškách.

Další důkazy o validitě jsme hledali ověřováním schopnosti nástroje diskriminovat na vysoké hladině významnosti mezi různými skupinami, konkrétně mezi dětmi bez a $\mathrm{s}$ diagnózou poruchy pozornosti. Využití testu pro diagnostiku deficitů regulace aktivity a pozornosti (ADHD, v poradenském kontextu VPCH) zůstává nejasné. Dle Barkleyho, Gradanskyho a DePaula (1992) jsou výsledky jednotlivých studií nekonzistentní - některé svědčí pro schopnost testu rozlišit mezi skupinami zdravých dětí a dětí s ADHD, jiné nikoliv. Navíc přetrvávají také nejasnosti ohledně důležitosti jednotlivých výstupů Testu cesty - některé studie hovoří o zvýšeném čase v TMT části $B$ u dětí $s$ ADHD, jiné o zvýšeném počtu chyb. V novější metaanalýze Willcutta et al. (2005) se schopnost Testu cesty rozlišit ve výkonech běžné děti a děti s diagnózou ADHD projevila výrazněji se střední velikostí efektu $(\mathrm{d}=0,55)$. V našem výzkumném vzorku byl zařazen pouze velmi malý počet respondentů s diagnózou vývojové poruchy chování (ADHD), studentů vedených na neurologii nebo psychiatrii, i studentů, kteří jsou kvůli neurologickým nebo psychiatrickým onemocněním medikováni, navíc tyto informace byly zjištovány pouze z anamnestického sdělení nikoliv vlastním vyšetřením - chybí nám tedy informace o závažnosti poruchy a způsobu léčení, není proto možné poskytnout bližší informace o schopnosti testu rozlišovat jednotlivé skupiny českých žákủ. Námi získané informace, včetně zdůraznění jejich omezeného využití, přesto uvádíme v př́loze č. 2 .

\section{Souvislosti základních a odvozených skórů}

Zajímavé je také bližší pohlédnutí na jednotlivé skóry, které poskytuje Test cesty. Dle dosavadních studií zabývajících se konstruktovou validitou metody odráží výsledek v části A Testu cesty zejména psychomotorické tempo, vizuální vyhledávání a mentální mapování (Chaytor et al., 2006; Sánchez-Cubillo et al., 2009). Na našich datech je částečnou oporou pro toto tvrzení nalezená souvislost mezi vlastním hodnocením svého pracovního tempa a výsledkem v TMTA a částečně také souvislost rychlosti čtení (hlasitého i tichého) s výkony v TMT v obou částech.

Část B je dle řady autorů ukazatelem zejm. kognitivní flexibility, schopnosti rozdělovat pozornost k více podnětům najednou a přepínat mezi nimi (Chaytor et al., 2006; SánchezCubillo et al., 2009). I zde je na našich datech možné nalézt částečnou oporu pro toto tvrzení v zaznamenané souvislosti vlastního hodnocení své pozornosti po testu s TMT B skórem, přičemž respondenti věděli, že administrovaný test je mj. testem pozornosti. Výsledek TMTA a TMTB spolu významně korelují, avšak vzhledem $\mathrm{k}$ vysvětlenému rozptylu je patrné, že skór TMTB na našich datech přináší také další informace (některé z nich jsou zmíněny výše). 
Odvozené skóry TMTB-A, resp. TMTB/A pak minimalizují vliv psychomotorického tempa a vizuální percepce a jsou nejlepším indikátorem schopnosti exekutivní kontroly (Hester et al., 2005; Sánchez-Cubillo et al., 2009). V souvislosti s interpretací odvozených skórů je $\mathrm{v}$ českém manuálu k metodě napsáno, že poměr TMTB/A v rozmezí 2-2,5 je možné brát jako normu, 3 jako kritický skór pro neurologické oslabení. Horší výkon než je doporučovaný kritický skór 3 v našem výzkumu dosáhlo 20,96 \% žáků, na základě těchto výsledků se nám hodnota kritický skóru 3 jeví jako velmi př́ísná. Navíc se ukázala významná souvislost poměrového skóru TMTB/A s typem navštěvované střední školy, domníváme se, že při podezření na neurologické oslabení by se tento fakt měl brát také v potaz. Velmi zajímavá je významná negativní korelace výsledku TMTA a poměrového skóru TMTB/A, což naznačuje, že čím respondenti pracovali pomaleji, tím lepší byla jejich exekutivní kontrola. Tento poznatek je možné využít při terapeutické práci s klienty a snažit se je systematicky vést $k$ pomalejší, ale přesnější práci.

V námi provedeném výzkumu se potvrdilo také tvrzení Chaytora et al. (2006), že TMTBA více než TMTB/A souvisí s prostým TMTB skórem. Na našich datech dokonce do té míry $(\mathrm{r}=0,91)$, že skór TMTB-A oproti TMTB nepřináší téměř žádné informace navíc. Vzhledem $\mathrm{k}$ této významné souvislosti není překvapením, že TMTB-A stejně jako prostý TMTB výsledek souvisí s ročníkem a typem navštěvované střední školy. Významně také souvisí se školními výsledky žáků, vlastním hodnocením své pozornosti po testu a vzděláním rodičů.

Někteří autoři (např. Hester et al., 2005) doporučují používat odvozené skóry vzhledem k jejich nižší závislosti na socioekonomických faktorech, zejména na věku a vzdělání. To se na našich datech potvrdilo pouze částečně pro TMTB/A, který je nezávislý na věku i navštěvovaném ročníku, souvisí však s typem navštěvované střední školy. Přesto vnímáme př́nos odvozeného skóru TMTB/A - kromě zmiňované informace o výrazném vlivu schopnosti exekutivní kontroly přináší ve shodě s Preissem a Preissem (2006) informaci o tom, $v$ jaké části testu se respondentovi vedlo lépe a v jaké části je jeho výkon oslaben.

V předkládané studii jsou uvedena normativní česká data pro Test cesty pro věkovou skupinu dospívajících, identifikovány faktory, které se významně podílí na výsledku v Testu cesty, a bliže prozkoumány také psychometrické charakteristiky metody. Pro praktické využití odbornými pracovníky je v př́loze č. 1 uveden metodický list pro práci s normami. Tato data pomohou pracovníkům pedagogicko-psychologických poraden lépe identifikovat žáky, u kterých je potenciál oslabení v oblasti pozornosti a exekutivních funkcí, s pomalejším pracovním tempem, a tedy s možnou potřebou podpůrných opatření ve vzdělávání. Data mohou být užitečná také pro klinické psychology při hodnocení neurologického oslabení dospívajících. Je však třeba zdůraznit, že se jedná o orientační zkoušku, která se navíc používá jen jako součást skríningových baterií. Nelze tedy usuzovat na př́padné oslabení př́slušných psychických funkcí jen na základě jediného výsledku v tomto testu. Bylo by vhodné provést další studii se zařazením většího počtu žáků s diagnostikovanou poruchou pozornosti, abychom lépe prozkoumali potenciál 
Testu cesty v českém prostředí diferencovat žáky s poruchou ADHD. Námi zjištěné informace o výkonech žáků s poruchou pozornosti jsou uvedeny v příloze č. 2. Žádoucí by také bylo dále ověřovat, které faktory ovlivňují výsledky jednotlivých dílčích skórů. 


\section{Zdroje}

Armstrong, C. M., Allen, D. N., Donohue, B., \& Mayfield, J. (2008). Sensitivity of the comprehensive trail making test to traumatic brain injury in adolescents. Archives of Clinical Neuropsychology, 23, 351-358. https://doi.org/10.1016/j.acn.2007.11.004

Barkley, R. A., Grodzinsky, G., \& DuPaul, G. J. (1992). Frontal Lobe Functions in Attention Deficit Disorder With and Without Hyperactivity: A Review and Research Report. Journal of Abnormal Child Psychology, 20(2), 163-188.

Bezdicek, O., Motak, L., Axelrod, B. N., Preiss, M., Nikolai, T., Vyhnalek, M., ... Ruzicka, E. (2012). Czech version of the trail making test: Normative data and clinical utility. Archives of Clinical Neuropsychology, 27(8), 906-914. https://doi.org/10.1093/arclin/acs084

Bezdicek, O., Moták, L., Schretlen, D. J., Preiss, M., Axelrod, B. N., Nikolai, T., ... Růžička, E. (2016). Sociocultural and Language Differences on the Trail Making Test. Archives of Assessment Psychology, 6(1), 33-48.

Bezdicek, O., Stepankova, H., Axelrod, B. N., Nikolai, T., Sulc, Z., Jech, R., ... Kopecek, M. (2017). Clinimetric validity of the Trail Making Test Czech version in Parkinson's disease and normative data for older adults. Clinical Neuropsychologist, 31(May 2017), 42-60. https://doi.org/10.1080/13854046.2017.1324045

Borsboom, D., Mellenbergh, G. J., \& Van Heerden, J. (2004). The concept of validity. Psychological Review, 111(4), 1061-1071. https://doi.org/10.1037/0033-295X.111.4.1061

Brown, E. C., Casey, A., Fisch, R. I., \& Neuringer, C. (1958). Trail Making Test as a Screening Device for the Detection of Brain Damage. Journal of Consulting Psychology, 22(6), 469-474.

Chaytor, N., Schmitter-Edgecombe, M., \& Burr, R. (2006). Improving the ecological validity of executive functioning assessment. Archives of Clinical Neuropsychology, 21(3), 217-227. https://doi.org/10.1016/j.acn.2005.12.002

Eisinga, R., te Grotenhuis, M., \& Pelzer, B. (2013). The reliability of a two-item scale: Pearson, Cronbach or Spearman-Brown? International Journal of Public Health, 58(4), 637-642. https://doi.org/10.1007/s00038-012-0416-3

Fernández, A. L., \& Marcopulos, B. A. (2008). A comparison of normative data for the Trail Making Test from several countries: Equivalence of norms and considerations for interpretation: Cognition and Neurosciences. Scandinavian Journal of Psychology, 49(3), 239-246. https://doi.org/10.1111/j.1467-9450.2008.00637.x

Hester, R. L., Kinsella, G. J., Ong, B., \& McGregor, J. (2005). Demographic influences on baseline and derived scores from the trail making test in healthy older Australian adults. The Clinical Neuropsychologist, 19(1), 45-54. https://doi.org/10.1080/13854040490524137

Lord, F. M., \& Novick, M. R. (1968). Statistical theories of mental test scores. Reading MA: AddisonWesley. https://doi.org/10.1039/tf9524800166

Mitrushina, M., Boone, K. B., Razani, J., \& D’Elia, L. F. (2005). Handbook of Normative Data for Neuropsychological Assessment. Oxford: University Press. https://doi.org/10.1016/S00057967(01)00037-7

Motýl, J. (2015). Test cesty. Recenze metody. Testfórum, (6), 47-52.

Odbor školství, mládeže a sportu K. úřadu M. kraje. (2017). Výroční zpráva o stavu a rozvoji vzdělávací soustavy v Moravskoslezském kraji za školní rok 2015/2016. Ostrava. 
Partington, J. E., \& Leiter, R. G. (1949). Partington's Pathways Test. Psychological Service Center Journal, 1, 11-20.

Preiss, M., \& Preiss, J. (2006). Test cesty. Př́ručka testu pro děti a dospělé. Brno: Psychodiagnostika.

Rabin, L. A., Barr, W. B., \& Burton, L. A. (2005). Assessment practices of clinical neuropsychologists in the United States and Canada: A survey of INS, NAN, and APA Division 40 members. Archives of Clinical Neuropsychology, 20(1), 33-65. https://doi.org/10.1016/j.acn.2004.02.005

Sánchez-Cubillo, I., Periáñez, J. A., Adrover-Roig, D., Rodríguez-Sánchez, J. M., Ríos-Lago, M., Tirapu, J., \& Barceló, F. (2009). Construct validity of the Trail Making Test: Role of task-switching, working memory, inhibition/interference control, and visuomotor abilities. Journal of the International Neuropsychological Society, 15(3), 438-450. https://doi.org/10.1017/S1355617709090626

Soukup, V. M., Ingram, F., Grady, J. J., \& Schiess, M. C. (1998). Trail Making Test : issues in Normative $\begin{array}{llll}\text { Data } & \text { Selection. } \quad \text { Applied } \quad \text { Neuropsychology, }\end{array}$ https://doi.org/10.1207/s15324826an0502

Tombaugh, T. N. (2004). Trail Making Test A and B : Normative data stratified by age and education. Archives of Clinical Neuropsychology, 19, 203-214. https://doi.org/10.1016/S0887-6177(03)00039-8

Urbánek, T. (2010). Nejpoužívanější psychodiagnostické metody v České republice. Testfórum, 1(1), 6-9. https://doi.org/10.5817/TF2010-1-3

Willcutt, E. G., Doyle, A. E., Nigg, J. T., Faraone, S. V, \& Pennington, B. F. (2005). Validity of the Executive Function Theory of Attention- Deficit / Hyperactivity Disorder : A Meta-Analytic Review. Society of Biological Psychiatry, (57), 1336-1346. https://doi.org/10.1016/j.biopsych.2005.02.006 


\title{
Hana Sokolová, Hynek Cígler (2018): Trail Making Test: Normative Czech data for students of 9 th grade primary school to 4th grade secondary school
}

\begin{abstract}
In the presented study, we provide normative Czech data for Trail Making Test (TMT) for students of 9th grade primary school to 4th grade secondary school. It was affirmed that it is not possible to accept TMT results from different cultural context. Results of Czech students were significantly lower when compared to the norms from abroad that are presented in the Czech manual as well as to results of other foreign studies. The factors related to TMT scores of Czech adolescents were identified - type of secondary school and number of student years, and in contrary to other studies, the relation of TMT scores with age was not documented. Psychometric characteristics were also explored. Methodical list for practical use of normative data is provided. Presented data will help clinical psychologists when assessing the neurological functions of adolescents and it might also be useful for psychologists working in education psychology field to identify students with special needs more accurately.
\end{abstract}

Key words: Trail Making Test, adolescents, Normative Czech data 


\section{Příloha 1: Metodické listy pro práci s normami k TMT pro skupinu adolescentů}

Sběr dat probíhal v březnu až dubnu 2017. Celkově se projektu zúčastnilo 584 žáků z okresu Nový Jičín z celkem 8 škol - 3 základních škol, 1 gymnázia, 2 odborných učilišt’ a 2 středních škol. Jednalo se o 388 dívek a 196 chlapců z 9. tříd ZŠ až 4. ročníků SŠ ve věku od 15 do 24 let. Chlapci a dívky se nelišili z hlediska věku. V tabulce 1 je uvedeno rozložení výzkumného vzorku z hlediska ročníku, pohlaví a typu navštěvované školy.

\begin{tabular}{|l|c|c|c|c|c|c|c|c|c|}
\hline & \multicolumn{2}{|c|}{ ZŠ } & \multicolumn{2}{c|}{ Gymnázium } & \multicolumn{2}{c|}{ SŠ } & \multicolumn{2}{c|}{ SOU } & $\begin{array}{c}\text { Celke } \\
\text { m }\end{array}$ \\
\hline & Dívky & Chlapci & Dívky & Chlapci & Dívky & Chlapci & Dívky & Chlapci & \\
\hline 9. tř́́da & 33 & 15 & 13 & 6 & - & & - & & 67 \\
\hline $\begin{array}{l}1 . \\
\text { ročník }\end{array}$ & - & - & 21 & 19 & 56 & 12 & 12 & 17 & 137 \\
\hline $\begin{array}{l}2 . \\
\text { ročník }\end{array}$ & - & - & 24 & 16 & 46 & 19 & 13 & 12 & 130 \\
\hline $\begin{array}{l}3 . \\
\text { ročník }\end{array}$ & - & - & 26 & 12 & 57 & 8 & 11 & 23 & 137 \\
\hline $\begin{array}{l}4 . \\
\text { ročník }\end{array}$ & - & - & 26 & 24 & 50 & 13 & - & - & 113 \\
\hline & 33 & 15 & 110 & 77 & 209 & 52 & 36 & 52 & \\
\hline Celkem & 48 & \multicolumn{2}{|c|}{187} & \multicolumn{2}{|c|}{261} & & & & \\
\hline
\end{tabular}

Z celkového počtu žáků nikdy nebylo v péči PPP 446 dětí, 73 dětí ano - at' už v současnosti, nebo v minulosti. Aktuálně dochází do PPP 47 žáků - 36 pro VPU, 2 pro VPCH a 9 pro VPU i VPCH zároveň.

U odborného lékaře - neurologa - je nyní vedeno 37 dětí, nejčastěji pro migrény a bolesti hlavy, bolesti zad a krční páteře, poruchy pozornosti, epilepsii, případně po úrazech hlavy. U psychiatra je v současnosti vedeno 14 dětí - pro poruchy pozornosti, úzkostné poruchy, depresi a další onemocnění (např. anorexie, Aspergerův syndrom, specifické fóbie). Jedno dítě je vedeno u obou odborníků. Léky na depresi, pozornost nebo úzkost nyní užívá 9 žáků.

Administrace probíhala standardně dle pokynů v manuálu (viz. Preiss \& Preiss, 20067). Vzhledem k věku respondentů jsme administrovali verzi pro dospělé, část A i B. Zaznamenávali jsme celkový čas v části A a části B a počet chyb.

\section{Výsledný čas}

Výsledný čas je možné srovnat s tabulkami norem na následujících stranách. Normy jsou prezentovány jako vážené skóry a percentily odpovídající jednotlivým hrubým skórům. Percentily byly zjištěny na základě rozložení dat a převedeny na vážené skóry na základě McCallovy plošné transformace.

Výkony žáků středních škol jsou rozděleny dle typu navštěvované školy a uvedené pro jednotlivé ročníky, ještě předtím je prezentována souhrnná tabulka pro žáky všech škol, opět dle navštěvovaného ročníku. Je to z toho důvodu, že u středoškoláků se ročník ${ }^{8} \mathrm{a}$

\footnotetext{
${ }^{7}$ Preiss, M. \& Preiss, J. (2006). Test cesty. Př́ručka testu pro děti a dospělé, 2. vydání. Brno: Psychodiagnostika.

${ }^{8}$ TMT část $A$ - Kendalovo $\tau=-0,075, p<0,05$, TMT část $B$ - Kendalovo $\tau=-0,086, p<0,01$
} 
typ navštěvované SŠ ${ }^{2}$ ukázaly jako faktory významně související s výkonem v TMT. U žáků 9. tříd nebyl nalezen rozdíl ve výkonech žáků základních škol a víceletých gymnázií, jsou tedy prezentována pouze souhrnná data ${ }^{10}$. Souvislost věku ${ }^{11}$ a výsledku v TMT na našich datech překvapivě nebyla prokázána.

\section{Chybovost v testu}

Autoři české verze testu v příručce uvádí, že více než jedna chyba v části B je některými autory považována za závažnou. Chyby jsou přičítány zejména poškození mozku vlivem impulzivity nebo tendenci perseverovat. Dále však uvádí, že i zdraví lidé dělají poměrně dost chyb (Lezaková et al., cit. dle Preiss \& Preiss, 2006).

V námi provedeném výzkumu udělalo v části A aspoň 1 chybu 14,2 \% respondentů, právě 1 chybu pak 12,3 \% žáků, maximum byly 2 chyby, kterých se dopustilo 1,9\% žáků. Pokud tedy žák udělá v části A již 1 chybu, je jeho výkon podprůměrný.

V části B alespoň jednou chybovalo 42,9 \% žáků, z nichž největší část (29,2 \%) se dopustilo 1 chyby, dále 2 chyby udělalo 9,9 \% žáků a 3 chyby 3,2 \% z celkového počtu respondentů. Maximum bylo 7 chyb, kterých se dopustil 1 žák.

\begin{tabular}{|c|c|c|c|}
\hline & Průměr & Podprůměr $(<15$. perc. $)$ & $\begin{array}{c}\text { Výr. podprůměr }(<2 . \\
\text { perc. })\end{array}$ \\
\hline Část A & 0 chyb & 1 chyba & 2 chyby \\
\hline Část B & $0-1$ chyba & 2 chyby & 3 chyby \\
\hline
\end{tabular}

Chybovost a délka zpracování testu spolu v části A nesouvisí, naopak v části B je souvislost chybovosti a rychlosti zpracování významná ${ }^{12}$.

\section{Poměr B/A}

Dle Mitrushiny a kolegů (2005) ${ }^{13}$ je možné interpretovat také poměr výsledku v TMTB/A. Dle informací v českém manuálu k metodě ${ }^{1}$ poměr nižší než 2 ukazuje na oslabení výkonu v části $\mathrm{A}$, poměr vyšší než 3 ukazuje na oslabení výkonu v části $\mathrm{B}$. Poměr v rozmezí 2-2,5 je možné brát jako normu, 3 jako kritický skór pro neurologické oslabení.

Z výše uvedených faktorů (věk ${ }^{14}$, ročník ${ }^{15}$, typ školy ${ }^{16}$ ) se ukázal jako statisticky významně související s poměrovým skórem $\mathrm{B} / \mathrm{A}$ pouze typ navštěvované střední školy. Horší výkon než je doporučovaný kritický skór 3 v našem výzkumu dosáhlo 27,6 \% studentů SOU, 19,5 \% studentů SŠ a 17,2 \% žáků gymnázia - ten se nám proto dle našich zjištění jeví jako velmi př́ísný. Vzhledem k nenormálnímu rozložení dat je však přesnější stanovovat poměrový kritický skór pro neurologické oslabení přes percentilové hodnoty - ty jsou uvedeny v tabulce níže.

\footnotetext{
${ }^{9}$ TMT část $A: F(2,530)=15,52, p<0,001, \mu=0,23$, část $B$ - Welchův test $F(2 ; 210,41)=19,91, p<0,001$

${ }^{10}$ TMT A: $t(49)=0,35, p>0,05$, TMT B: $t(48)=0,81, p>0,05$

${ }^{11}$ TMT část $A: \tau=-0,04, p=0,208$, TMT část $B: \tau=-0,06, p=0,057$

12 TMTA: $\tau=0,01, p=0,77$, TMTB: $\tau=0,40, p<0,001$

${ }^{13}$ Mitrushina, M., Boone, K. B., Razani, J., \& D’Elia, L. F. (2005). Handbook of Normative Data for Neuropsychological Assessment (p. 1015). Oxford: University Press. doi:10.1016/S0005-7967(01)00037-7

${ }^{14} \mathrm{TMTB} / \mathrm{A}, \tau=-0,01, \mathrm{p}=0,933$.

${ }^{15} \mathrm{TMTB} / \mathrm{A}, \tau=-0,02, \mathrm{p}=0,637$

${ }^{16}$ TMTB/A: $F(2,527)=3,20, p=0,041$.
} 


\begin{tabular}{|c|c|c|c|}
\hline \multicolumn{4}{|c|}{ TMTB/A } \\
\hline & SOU & Š̌ & Gymnázium \\
\hline 85. percentil & 3,54 & 3,32 & 3,08 \\
\hline 95. percentil & 4,39 & 4,66 & 4,17 \\
\hline
\end{tabular}

\section{Rozdíl B-A}

V interpretacích testu autoři různých studií často pracují také s rozdílem v TMTB-A. Na ten je výhodné se rovněž podívat, nebot' je dle některých autorů (např. Sanchéz- Cubillo et al, 200917) nejlepším ukazatelem schopnosti exekutivní kontroly při minimalizaci vlivu vizuální percepce a pracovní paměti.

Skór TMTB-A v námi provedeném šetření významně koreluje s prostým TMT B skórem ( $\mathrm{r}=0,91, \mathrm{p}<0,001)$, rozdílový skór tedy na našich datech nepřináší oproti prostému TMTB skóru příliš informací navíc.

\footnotetext{
${ }^{17}$ Sánchez-Cubillo, I., Periáñez, J. A., Adrover-Roig, D., Rodríguez-Sánchez, J. M., Ríos-Lago, M., Tirapu, J., \& Barceló, F. (2009). Construct validity of the Trail Making Test : Role of task-switching , working memory , inhibition / interference control , and visuomotor abilities. Journal of International Neuropsychological Society, (15), 438-450. doi:10.1017/S1355617709090626
} 


\section{Normy pro TMT A Všichni žáci bez ohledu na typ navštěvované školy $(\mathrm{N}=561)^{18}$}

\begin{tabular}{|c|c|c|c|c|c|c|}
\hline Percentil & VS & 9. tř́́da & 1. ročník & 2. ročník & 3. ročník & 4. ročník \\
\hline 98. & 130 & 12,04 & 14,74 & 14,74 & 14,00 & 14,00 \\
\hline 95. & 125 & 15,40 & 16,00 & 16,00 & 16,00 & 15,70 \\
\hline 90. & 119 & 20,20 & 18,00 & 18,00 & 18,00 & 17,00 \\
\hline 85. & 116 & 21,00 & 19,00 & 19,00 & 18,00 & 18,00 \\
\hline 80. & 113 & 23,00 & 21,00 & 21,00 & 19,00 & 19,00 \\
\hline 75. & 110 & 25,00 & 22,00 & 22,00 & 20,00 & 20,00 \\
\hline 70. & 108 & 25,00 & 23,00 & 23,00 & 21,00 & 21,00 \\
\hline 65. & 106 & 25,20 & 25,00 & 25,00 & 22,00 & 22,00 \\
\hline 60. & 104 & 26,80 & 26,80 & 26,80 & 24,00 & 23,00 \\
\hline 55. & 102 & 27,40 & 27,00 & 27,00 & 25,00 & 24,00 \\
\hline 50. & 100 & 29,00 & 28,00 & 28,00 & 27,00 & 25,00 \\
\hline 45. & 98 & 30,60 & 29,00 & 29,00 & 28,00 & 26,00 \\
\hline 40. & 96 & 32,00 & 30,20 & 30,20 & 29,00 & 28,40 \\
\hline 35. & 94 & 34,80 & 32,00 & 32,00 & 30,00 & 30,00 \\
\hline 30. & 92 & 36,40 & 33,00 & 33,00 & 32,00 & 32,80 \\
\hline 25. & 90 & 39,00 & 34,00 & 34,00 & 34,00 & 35,00 \\
\hline 20. & 87 & 40,60 & 37,00 & 37,00 & 36,00 & 35,20 \\
\hline 15. & 84 & 42,00 & 41,00 & 41,00 & 38,00 & 38,90 \\
\hline 10. & 81 & 48,00 & 46,30 & 46,30 & 40,00 & 41,60 \\
\hline 5. & 75 & 53,60 & 52,30 & 52,30 & 45,10 & 46,30 \\
\hline 2. & 70 & 61,76 & 71,56 & 71,56 & 54,24 & 52,32 \\
\hline
\end{tabular}

Normy pro TMT B Všichni žáci bez ohledu na typ navštěvované školy ( $\mathrm{N}=561)$

\begin{tabular}{|c|c|c|c|c|c|c|}
\hline Percentil & VS & 9. třída & 1. ročník & 2. ročník & 3. ročník & 4. ročník \\
\hline 98. & 130 & 28,06 & 30,74 & 30,74 & 27,16 & 26,28 \\
\hline 95. & 125 & 31,55 & 37,70 & 37,70 & 37,80 & 32,40 \\
\hline 90. & 119 & 41,00 & 41,00 & 41,00 & 44,60 & 36,00 \\
\hline 85. & 116 & 43,30 & 45,00 & 45,00 & 48,40 & 40,10 \\
\hline 80. & 113 & 49,20 & 46,00 & 46,00 & 50,00 & 41,80 \\
\hline 75. & 110 & 50,75 & 49,00 & 49,00 & 51,00 & 44,00 \\
\hline 70. & 108 & 54,00 & 52,10 & 52,10 & 53,00 & 46,00 \\
\hline 65. & 106 & 54,85 & 55,00 & 55,00 & 54,60 & 49,90 \\
\hline 60. & 104 & 57,00 & 57,80 & 57,80 & 57,00 & 51,60 \\
\hline 55. & 102 & 61,00 & 60,65 & 60,65 & 59,00 & 53,00 \\
\hline 50. & 100 & 66,00 & 63,50 & 63,50 & 61,00 & 54,00 \\
\hline 45. & 98 & 68,00 & 68,35 & 65,35 & 65,00 & 57,70 \\
\hline 40. & 96 & 69,60 & 69,00 & 69,00 & 68,00 & 59,40 \\
\hline 35. & 94 & 73,30 & 73,05 & 73,05 & 70,00 & 62,00 \\
\hline 30. & 92 & 77,00 & 75,90 & 75,90 & 74,00 & 64,00 \\
\hline 25. & 90 & 80,00 & 80,50 & 80,50 & 77,00 & 68,00 \\
\hline 20. & 87 & 86,00 & 89,60 & 89,60 & 85,60 & 70,40 \\
\hline 15. & 84 & 91,50 & 99,35 & 99,35 & 93,00 & 75,00 \\
\hline 10. & 81 & 101,00 & 107,00 & 107,00 & 109,20 & 79,00 \\
\hline 5. & 75 & 129,45 & 121,45 & 121,45 & 122,00 & 98,50 \\
\hline 2. & 70 & 158,86 & 132,34 & 132,34 & 133,56 & 119,16 \\
\hline
\end{tabular}

\footnotetext{
${ }^{18} \mathrm{~V}$ následujících tabulkách jsou vždy ve sloupcích pod ročníky uvedeny hrubé skóry (čas v sekundách), ke kterým je v prvních dvou sloupcích uveden odpovídající percentil a vážený skór (M=100, SD=15).
} 


\section{Normy pro TMT A pro žáky SOU $(\mathrm{N}=88)$}

\begin{tabular}{|c|c|c|c|c|}
\hline Percentil & VS & 1. ročník & 2. ročník & 3. ročník \\
\hline 98. & 130 & 16,00 & - & 16,00 \\
\hline 95. & 125 & 17,00 & - & 17,50 \\
\hline 90. & 119 & 18,00 & 16,00 & 18,00 \\
\hline 85. & 116 & 23,00 & 21,40 & 20,75 \\
\hline 80. & 113 & 24,00 & 24,00 & 24,00 \\
\hline 75. & 110 & 27,00 & 24,50 & 25,75 \\
\hline 70. & 108 & 28,00 & 25,80 & 27,50 \\
\hline 65. & 106 & 29,00 & 27,00 & 28,50 \\
\hline 60. & 104 & 31,00 & 27,80 & 30,00 \\
\hline 55. & 102 & 31,00 & 29,70 & 32,00 \\
\hline 50. & 100 & 34,00 & 30,00 & 33,00 \\
\hline 45. & 98 & 34,00 & 30,30 & 33,25 \\
\hline 40. & 96 & 34,00 & 31,60 & 34,00 \\
\hline 35. & 94 & 35,50 & 34,70 & 36,75 \\
\hline 30. & 92 & 39,00 & 36,40 & 37,50 \\
\hline 25. & 90 & 50,00 & 39,00 & 39,25 \\
\hline 20. & 87 & 51,00 & 40,00 & 40,00 \\
\hline 15. & 84 & 53,00 & 40,50 & 41,00 \\
\hline 10. & 81 & 59,00 & 46,60 & 43,00 \\
\hline 5. & 75 & 78,50 & 51,80 & 56,25 \\
\hline 2. & 70 & - & - & - \\
\hline
\end{tabular}

\section{Normy pro TMT B pro žáky SOU $(\mathrm{N}=88)$}

\begin{tabular}{|c|c|c|c|c|}
\hline Percentil & VS & 1. ročník & 2. ročník & 3. ročník \\
\hline 98. & 130 & 41,00 & 33,00 & 48,00 \\
\hline 95. & 125 & 42,80 & 34,50 & 48,75 \\
\hline 90. & 119 & 48,60 & 40,40 & 50,00 \\
\hline 85. & 116 & 55,70 & 44,70 & 51,00 \\
\hline 80. & 113 & 59,40 & 54,00 & 55,00 \\
\hline 75. & 110 & 63,25 & 58,00 & 60,75 \\
\hline 70. & 108 & 66,80 & 58,80 & 62,00 \\
\hline 65. & 106 & 69,00 & 62,30 & 63,00 \\
\hline 60. & 104 & 70,20 & 65,40 & 68,00 \\
\hline 55. & 102 & 73,05 & 66,70 & 69,75 \\
\hline 50. & 100 & 74,00 & 76,00 & 75,00 \\
\hline 45. & 98 & 78,75 & 77,00 & 76,25 \\
\hline 40. & 96 & 79,80 & 78,80 & 79,00 \\
\hline 35. & 94 & 83,55 & 80,00 & 83,50 \\
\hline 30. & 92 & 97,50 & 91,20 & 91,00 \\
\hline 25. & 90 & 107,75 & 105,00 & 103,25 \\
\hline 20. & 87 & 121,60 & 115,60 & 108,00 \\
\hline 15. & 84 & 127,90 & 129,70 & 114,00 \\
\hline 10. & 81 & 130,90 & 136,00 & 127,00 \\
\hline 5. & 75 & 154,40 & 147,20 & 136,25 \\
\hline 2. & 70 & - & - & - \\
\hline
\end{tabular}




\section{Normy pro TMT A pro žáky SŠ s maturitou $(\mathrm{N}=261)$}

\begin{tabular}{|c|c|c|c|c|c|}
\hline Percentil & VS & 1. ročník & 2. ročník & 3. ročník & 4. ročník \\
\hline 98. & 130 & 14,38 & 12,64 & 11,28 & 14,56 \\
\hline 95. & 125 & 16,00 & 15,30 & 15,30 & 16,00 \\
\hline 90. & 119 & 17,00 & 16,60 & 17,60 & 17,00 \\
\hline 85. & 116 & 19,00 & 18,00 & 18,00 & 18,00 \\
\hline 80. & 113 & 20,00 & 18,00 & 19,00 & 19,00 \\
\hline 75. & 110 & 21,25 & 20,00 & 20,00 & 20,00 \\
\hline 70. & 108 & 23,00 & 21,00 & 20,00 & 21,00 \\
\hline 65. & 106 & 24,15 & 23,00 & 21,00 & 22,40 \\
\hline 60. & 104 & 25,60 & 23,00 & 22,00 & 23,60 \\
\hline 55. & 102 & 26,05 & 24,00 & 23,00 & 25,00 \\
\hline 50. & 100 & 27,00 & 25,00 & 24,00 & 26,00 \\
\hline 45. & 98 & 27,00 & 25,30 & 27,00 & 28,20 \\
\hline 40. & 96 & 29,00 & 26,00 & 27,60 & 29,40 \\
\hline 35. & 94 & 29,85 & 27,00 & 28,00 & 33,20 \\
\hline 30. & 92 & 31,00 & 28,00 & 29,20 & 34,00 \\
\hline 25. & 90 & 33,00 & 30,50 & 31,00 & 35,00 \\
\hline 20. & 87 & 33,20 & 33,00 & 32,00 & 36,00 \\
\hline 15. & 84 & 34,65 & 36,00 & 34,10 & 39,40 \\
\hline 10. & 81 & 43,30 & 37,40 & 37,40 & 42,60 \\
\hline 5. & 75 & 49,55 & 42,50 & 45,40 & 46,80 \\
\hline 2. & 70 & 69,92 & 49,40 & 47,00 & 58,32 \\
\hline
\end{tabular}

Normy pro TMT B pro žáky SŠ s maturitou (N=261)

\begin{tabular}{|c|c|c|c|c|c|}
\hline Percentil & VS & 1. ročník & 2. ročník & 3. ročník & 4. ročník \\
\hline 98. & 130 & 31,14 & 27,28 & 25,96 & 34,00 \\
\hline 95. & 125 & 36,90 & 32,30 & 35,60 & 35,20 \\
\hline 90. & 119 & 40,80 & 39,00 & 41,60 & 39,40 \\
\hline 85. & 116 & 45,00 & 41,80 & 44,00 & 42,00 \\
\hline 80. & 113 & 46,00 & 43,00 & 49,20 & 44,80 \\
\hline 75. & 110 & 49,00 & 45,00 & 50,50 & 48,00 \\
\hline 70. & 108 & 52,40 & 46,00 & 52,80 & 50,20 \\
\hline 65. & 106 & 54,00 & 52,10 & 54,00 & 53,00 \\
\hline 60. & 104 & 56,20 & 55,00 & 54,40 & 53,60 \\
\hline 55. & 102 & 60,00 & 56,70 & 56,70 & 56,60 \\
\hline 50. & 100 & 61,50 & 58,00 & 58,00 & 59,00 \\
\hline 45. & 98 & 65,00 & 62,30 & 59,30 & 60,00 \\
\hline 40. & 96 & 66,40 & 64,00 & 65,60 & 62,00 \\
\hline 35. & 94 & 71,00 & 66,00 & 67,90 & 64,00 \\
\hline 30. & 92 & 74,30 & 68,00 & 69,20 & 67,80 \\
\hline 25. & 90 & 76,75 & 72,50 & 73,50 & 69,00 \\
\hline 20. & 87 & 83,00 & 76,80 & 75,00 & 75,20 \\
\hline 15. & 84 & 91,65 & 80,40 & 86,00 & 80,60 \\
\hline 10. & 81 & 102,20 & 92,00 & 89,40 & 95,40 \\
\hline 5. & 75 & 111,95 & 108,00 & 110,50 & 115,60 \\
\hline 2. & 70 & 124,68 & 118,68 & 128,92 & 122,88 \\
\hline
\end{tabular}




\section{Normy pro TMT A pro žáky gymnázia $(\mathrm{N}=187)$}

\begin{tabular}{|c|c|c|c|c|c|}
\hline Percentil & VS & 1. ročník & 2. ročník & 3. ročník & 4. ročník \\
\hline 98. & 130 & 12,00 & 13,00 & 14,00 & 13,02 \\
\hline 95. & 125 & 15,00 & 15,05 & 15,90 & 14,55 \\
\hline 90. & 119 & 17,00 & 17,00 & 16,00 & 17,00 \\
\hline 85. & 116 & 19,00 & 17,00 & 17,70 & 18,00 \\
\hline 80. & 113 & 19,00 & 17,20 & 18,00 & 19,20 \\
\hline 75. & 110 & 21,00 & 18,25 & 18,75 & 20,00 \\
\hline 70. & 108 & 21,00 & 19,00 & 20,00 & 21,00 \\
\hline 65. & 106 & 22,00 & 21,00 & 21,00 & 22,00 \\
\hline 60. & 104 & 23,00 & 22,00 & 21,60 & 23,00 \\
\hline 55. & 102 & 27,00 & 23,00 & 23,55 & 23,95 \\
\hline 50. & 100 & 27,00 & 23,50 & 24,50 & 24,50 \\
\hline 45. & 98 & 29,00 & 24,00 & 25,00 & 25,05 \\
\hline 40. & 96 & 30,00 & 24,60 & 26,80 & 26,00 \\
\hline 35. & 94 & 32,00 & 26,30 & 29,35 & 28,15 \\
\hline 30. & 92 & 33,00 & 29,00 & 30,00 & 30,00 \\
\hline 25. & 90 & 36,00 & 31,75 & 31,75 & 32,25 \\
\hline 20. & 87 & 39,00 & 33,00 & 36,20 & 35,00 \\
\hline 15. & 84 & 40,00 & 39,55 & 38,00 & 38,70 \\
\hline 10. & 81 & 41,00 & 41,00 & 40,00 & 41,00 \\
\hline 5. & 75 & 44,00 & 49,60 & 44,55 & 46,35 \\
\hline 2. & 70 & - & - & - & 48,00 \\
\hline
\end{tabular}

\section{Normy pro TMT B pro žáky gymnázia $(\mathrm{N}=187)$}

\begin{tabular}{|c|c|c|c|c|c|}
\hline Percentil & VS & 1. ročník & 2. ročník & 3. ročník & 4. ročník \\
\hline 98. & 130 & 27,00 & 31,00 & 25,00 & - \\
\hline 95. & 125 & 31,15 & 31,10 & 32,65 & 26,55 \\
\hline 90. & 119 & 38,10 & 34,10 & 45,40 & 31,20 \\
\hline 85. & 116 & 40,15 & 35,45 & 48,00 & 36,00 \\
\hline 80. & 113 & 41,20 & 39,20 & 48,40 & 40,20 \\
\hline 75. & 110 & 44,50 & 41,50 & 49,00 & 41,00 \\
\hline 70. & 108 & 46,30 & 44,60 & 50,00 & 43,00 \\
\hline 65. & 106 & 48,05 & 46,35 & 52,85 & 44,00 \\
\hline 60. & 104 & 50,80 & 48,40 & 54,00 & 46,20 \\
\hline 55. & 102 & 53,80 & 52,00 & 55,65 & 49,00 \\
\hline 50. & 100 & 58,00 & 54,50 & 58,50 & 51,50 \\
\hline 45. & 98 & 60,55 & 56,55 & 59,35 & 53,05 \\
\hline 40. & 96 & 63,00 & 58,00 & 61,80 & 55,20 \\
\hline 35. & 94 & 65,00 & 59,65 & 65,00 & 56,30 \\
\hline 30. & 92 & 67,40 & 60,70 & 68,60 & 60,10 \\
\hline 25. & 90 & 74,75 & 67,25 & 73,50 & 62,75 \\
\hline 20. & 87 & 85,20 & 72,60 & 81,20 & 67,40 \\
\hline 15. & 84 & 90,70 & 76,40 & 95,50 & 73,05 \\
\hline 10. & 81 & 102,90 & 80,80 & 113,4 & 75,00 \\
\hline 5. & 75 & 109,80 & 102,90 & 122,15 & 77,35 \\
\hline 2. & 70 & - & - & - & 87,82 \\
\hline
\end{tabular}




\section{Př́loha 2: Možnosti diagnostiky poruch pozornosti Testem cesty u českých adolescentů}

Test cesty bývá velmi často využíván pro diagnostiku pozornosti a deficitů exekutivních funkcí (Rabin et al., 2005; Willcutt et al., 2005). Jak je zmíněno v Diskuzi článku, přesto zůstává využití testu pro diagnostiku deficitů regulace aktivity a pozornosti (ADHD, vporadenském kontextu VPCH) nejasné a výsledky jednotlivých studií jsou nekonzistentní (Barkley, Gradansky \& DePaula, 1992).

Z toho důvodu nás zajímalo, do jaké míry je TMT schopen na našich datech diskriminovat mezi dětmi bez a s diagnózou poruchy pozornosti. Tyto informace uvádíme v př́loze $\mathrm{z}$ toho důvodu, že v našem šetření byl pouze velmi malý počet studentů s ADHD a zejména proto, že o diagnóze ADHD jsme se dozvídali na základě anamnestického sdělení respondentů, nikoliv na základě vyšetření. Neměli jsme tedy bližší informace o závažnosti poruchy, což samozřejmě může mít výrazný vliv na výkony respondentů v testu. Rovněž informace o neurologické nebo psychiatrické péči jsme se dozvídali přímo od respondentů. Navíc ve skupině respondentů, kteří byli pro statistické analýzy zařazeni ve skupině žáků vedených na neurologii nebo psychiatrii, byli zařazení žáci bez ohledu na konkrétní diagnózu, se kterou k lékaři dochází. I toto je limitem a proto jsou informace o schopnosti testu na našich datech rozlišovat jednotlivé skupiny žáků pouze orientační, bylo by zapotřebí provést detailnější klinickou studii. Přesto vnímáme jako užitečné je na tomto místě uvést.

Na našich datech nebyla pozorována schopnost nástroje rozlišit výkon dětí s poruchami pozornosti vedených s touto diagnózou v PPP $(n=11)$ od výkonu žáků bez poruchy pozornosti potvrzené v PPP v části A z hlediska rychlosti, $W=157859,5, z=-0,08, p=0,934$, $\mathrm{r}=0,03$, ani počtu chyb: $\mathrm{W}=2962,50, \mathrm{z}=-0,51, \mathrm{p}=0,609$, stejně tak $\mathrm{v}$ části B není ve výkonech rozdíl z hlediska času, $\mathrm{W}=2907,0, \mathrm{z}=-0,37, \mathrm{p}=0,708, \mathrm{r}=0,01$, ani chybovosti, $\mathrm{W}=157201,0$, $\mathrm{z}=-0,30, \mathrm{p}=0,767$. Rozdíl není patrný ani $\mathrm{z}$ hlediska odvozených skórů: TMTB-A: $\mathrm{W}=3071,0, \mathrm{z}=-0,058, \mathrm{p}=0,954, \mathrm{TMTB} / \mathrm{A}: \mathrm{W}=2744,0, \mathrm{z}=-0,67, \mathrm{p}=0,503$.

Obdobně se signifikantně nelišily výkony žáků aktuálně vedených na neurologii nebo psychiatrii $(\mathrm{n}=54)$ od výkonu žáků, kteří aktuálně vedeni na neurologii nebo psychiatrii nejsou. Č́st A: rychlost $\mathrm{W}=13$ 811,0, $\mathrm{z}=-1,33, \mathrm{p}=0,183, \mathrm{r}=0,06$, chybovost, $\mathrm{W}=145554,0$, $\mathrm{z}=-0,98, \mathrm{p}=0,329$; část $\mathrm{B}$ : rychlosti $\mathrm{W}=15221,0, \mathrm{z}=-0,03, \mathrm{p}=0,976, \mathrm{r}=0,001$, ani chybovosti $\mathrm{W}=143765,0, \mathrm{z}=-1,37, \mathrm{p}=0,172$. Rozdíl nebyl nalezen ani v odvozených skórech, TMTB-A: $\mathrm{W}=142815,0, \mathrm{z}=-0,64, \mathrm{p}=0,525$, TMTB/A: $\mathrm{W}=142062,0, \mathrm{z}=-1,30, \mathrm{p}=0,194$.

Nepozorovali jsme ani rozdíl ve výkonu žáků, kteří jsou aktuálně medikováni kvůli neurologickému nebo psychiatrickému onemocnění (konkrétně kvůli obtížím s pozorností nebo kvůli depresi) ( $\mathrm{n}=9$ ), od výkonu žáků, kteří aktuálně medikováni nejsou - v části A: rychlost: $\mathrm{W}=2469,5, \mathrm{z}=-0,17, \mathrm{p}=0,866, \mathrm{r}=0,01$, chybovost: $\mathrm{W}=158276,0, \mathrm{z}=-$ 0,67, p=0,506, ani v části B: rychlost: $W=2029,0, z=-1,05, p=0,293, r=0,04$, chybovost: $W=2300,0, z=-0,57, p=0,567$. TMTB-A: $W=2244,5, z=-0,598, p=0,550$, TMTB/A: $W=2460$, $\mathrm{z}=-0,15, \mathrm{p}=0,879$. 
TESTFÓRUM, 2018, č. 11, s. 1-20

www.testforum.cz

Hana Sokolová, Hynek Cígler: Test cesty: Normativní česká data pro žáky 9. tříd ZŠ až 4. ročníků SŠ

Znovu však opakujeme, že se jedná pouze o orientační data. Bylo by velice užitečné, pokud by byla schopnost nástroje odlišit včeském kontextu děti s ADHD podrobněji prozkoumána v rámci klinické studie. 